\title{
Knowledge Domains, Technological Strategies and Open Innovation
}

\author{
Francesca Michelino', Antonello Cammarano², Emilia Lamberti' ${ }^{3}$,Mauro Caputo ${ }^{4}$
}

\begin{abstract}
This study provides a patent-based framework, investigating the relationship among the relevance of the technological domains, the exploitation vs. exploration strategies and the choice of open innovation practices. Specifically, this work presents five levels of open innovation adoption and analyses the reason why firms open up their innovation boundaries. The methodology is tested on a sample of 240 companies belonging to the bio-pharmaceutical and the technology hardware \& equipment industries, by examining their patents filed in 2011. Results show that the relevance of the knowledge domain affects the choice of the innovation strategy; also, non-equity alliances are preferred in explorative activities and equity alliances in exploitative ones.
\end{abstract}

Keywords: knowledge domains; exploitation vs. exploration; technological fields; innovation strategies; organizing for innovation; decentralized r\&d activities; open innovation; patent data analysis; bio-pharmaceutical; technology hardware \& equipment.

\footnotetext{
1,2,3,4 Department of Industrial Engineering, University of Salerno,Via Giovanni Paolo II, I 32 - 84084 - Fisciano (SA), Italy. Phone: +39 0899640934. e-mail: mcaputo@unisa.it (corresponding author)
} 


\section{Introduction}

Technological innovation is characterised by intense searching activities addressed to identify and solve technical problems. The innovation literature focused on two different strategies that companies may adopt in order to develop new technologies: a) the exploitation and recombination of pieces of knowledge already owned and b) the exploration of new technological domains through the search for new ideas and the accumulation of new useful knowledge (Archibugi and Pianta, 1996). Firms operate using a wide range of knowledge domains and differ in their technological diversity (Pavitt et al., 1989). Furthermore, in industries featured by intense research and development (R\&D) activities, the competencies required to manufacture a product include multiple knowledge domains. This lead to the adoption of several technological strategies among firms in order to pursue a competitive advantage in the industry in which each company is involved. The correct balance between exploitation and exploration strategies is required for combining existing knowledge with new one. This process is not static, with companies expanding their breadth of knowledge over time (Pavitt et al., 1989; Chang, 1996; Miller, 2004).

Technological strategies also lead to the identification of specific technological domains that are crucial for firms. Since not all the domains are relevant for the company, some knowledge areas are strongly stressed and mostly contribute to the development of the core technology of current business activities.

In addition, the innovation strategies affect the organization of R\&D activities, mainly on the choice of carrying out the entire innovative effort within the firm or not. The boundaries of innovating companies are in fact changing: in the last decade inter-firm R\&D collaborations, strategic technological alliances, joint development with universities and research groups, complex innovation networks and joint venturing investments have been incorporated into firms' technological strategies, since they give access to different knowledge bases and new resources. In 2003 Henry Chesbrough introduced the open innovation (OI) paradigm with the aim of synthesize the mix of innovation practices that involve companies in the co-development of new products and technologies.

Furthermore, companies are rebuilding their internal R\&D organization: the importance of large in-house laboratories is declining and the international dimension of the innovation process is increasing (Archibugi and Pianta, 1996). Firms decentralize their R\&D activities and even more involve their subsidiaries in the technological development.
Since patent data are the only formally and publicly verified outputs of inventive activities, are widely accepted as a measure of innovation and are used as a means of appropriation of innovation in industries characterized by intense R\&D activities (Pavitt, 1984), we developed a patentbased framework in order to understand which factors affect the choice of Ol practices, defining the relationship with the relevance of the technological domains and the exploitation vs. exploration strategies. The methodology is tested on a sample of 240 R\&D intense companies from bio-pharmaceutical and technology hardware \& equipment industries, by analysing their patents filed in $20 \mathrm{I}$ I, validating both the framework applicability and its explicative power and usefulness. The analysis of the behaviours of companies showed that non-equity alliances, significantly affecting firms' business models, are preferred in explorative activities and equity alliances in exploitative ones. We also found that exploitation strongly prevails on exploration and that innovation strategies vary depending on the relevance of the knowledge domain involved into the process.

In what follows, after a literature review on knowledge domains, management and organization of innovation and patent-based metrics for innovation, the measurement framework is presented and then applied to the sample. Results are discussed and conclusions will close the work.

\section{Literature review}

\section{Knowledge domains: exploration vs. exploitation and their relevance}

The technology of a firm is the result of its accumulated experience in design, production, problem-solving and trouble-shooting activities. Companies progressively accumulate their technological knowledge, therefore firm's existing stock of knowledge is history dependent and affects its future technological development (Tsang, 1997). Technological innovation is characterized by searching activities of optimal alternatives addressed to identify and solve technical problems (Nelson and Winter, 1982). Through such activities companies may improve their current technological capability or develop new capabilities. Technological innovations are based on the recombination and the integration of capabilities belonging to different knowledge domains, therefore such processes depend on the experience accumulated by the company. Actually, companies operate using a wide range of knowledge domains and differ in their technological diversity (Pavitt et al., 1989). Furthermore, in industries characterised by intense R\&D activities, the competencies required to manufacture a product include multiple knowledge domains. Therefore, companies pursue different innovation approaches that lead to different innovation performances, depending on the 
specific technological strategy adopted in order to achieve a competitive advantage in the industry in which each firm is involved.This process is not static, with companies expanding their breadth of knowledge over time (Pavitt et al., 1989; Chang, 1996; Miller, 2004): knowledge does not have a rigid nature, but it can be transformed, accumulated, stored and transferred (Lo Storto, 2006).

The dynamic evolution of capabilities is influenced by the exploitation vs. exploration strategy adopted by a company. March (199I) made an explicit distinction between exploration and exploitation; the former refers to the creation of new capabilities by means of activities such as fundamental research, experimentation, and search. The latter concerns the leveraging of existing capabilities by means of activities such as standardization, upscaling, and refinement. Specifically, exploitation strategies are associated with experiential refinement, selection, reuse of existing routines, upscaling, standardization and recombination and are aimed at strengthening basic knowledge already owned by a company, increasing the degree of novelty with a limited risk, within the boundaries of the present concepts and architectures (Simon, 1991). Exploitative activities improve the effectiveness and the efficiency of existing capabilities, require the creation of economies of scale and lead to short-term effects (Belderbos et al., 2010). Exploitation, more often than not, generates incremental knowledge with moderate but certain and immediate returns (Schulz, 200I). Therefore, exploitative strategies are based on the local search and build on the existing technological trajectory, aiming at improving existing product-market domains ( $\mathrm{He}$ and Wong, 2004). On the other hand, the exploration of new possibilities and ideas is based on distant search and associated with experimentation, play, risk taking, in order to both create new capabilities (Belderbos et al., 2010) and produce new knowledge (Miner et al., 200 I). Such novel body of knowledge will serve as the seed for future technological development (Miller et al., 2007) with companies involved in shifting to a different technological trajectory (Benner and Tushman, 2002) and aiming at entering new product-market domains (He and Wong, 2004) in order to achieve a longterm growth. Moreover, to execute distant search, a firm must identify distant knowledge domains from outside its boundaries and transfer them inside (Miller et al., 2007). For instance, firms' members may attend conferences, browse patents, read trade journal or reverse-engineer competing products. Otherwise, companies may hire new skilled personnel in order to acquire their competencies in specific technological domains. In general, the capability to assimilate, assess and use new knowledge depends on firm's absorptive capacity (Cohen and Levinthal, 1990).
Even though exploration and exploitation compete for scarce organizational resources (March, I991; 1996; 2006) and are self-reinforcing, adopting only one strategy may lead to a trap. Exploitation leads to early success, but often creates a success trap, with existing core capabilities turning into core rigidities, reducing the ability of the firm to adequately respond to technological changes and compromising the long-term survival (Leonard-Barton, 1992; Christensen and Overdorf, 2000). Differently, exploration often leads to failure and requires high commitment and investments, thus relying solely on it negatively affects firm's financial performance (i.e. failure trap). Therefore, firms benefit from a balanced mix of exploration and exploitation strategies and the combination of both strategies improves survival chances, growth and financial performances (O'Reilly and Tushman, 2004). Gupta et al. (2006) suggested that within a single technological domain exploration and exploitation are mutually exclusive, whilst across different areas they are orthogonal, thus high levels of exploration or exploitation in a specific domain may coexist with high levels of exploration or exploitation on other ones.

Although scientific literature aimed at identifying the impact of exploitation vs. exploration activities, no contribution was uncovered about the relationship between such activities and the relevance of the specific knowledge domain in which a technological strategy was adopted. As a matter of fact, not all the domains are relevant for the company: only some knowledge areas are strongly stressed and mostly contribute to the development of the core technology of current business activities.

\section{Management and organization of innovation}

Regarding the organizational dimension of R\&D, companies can carry out the entire innovative effort within their boundaries, pursuing a closed innovation $(\mathrm{Cl})$ strategy, or open up their R\&D processes, adopting an Ol strategy.

In the closed system, new products and services are developed in-house and exploited by the company to enter the market first and win, whereas in the open one innovations are the result of collaboration efforts with third parties. Carrying on a $\mathrm{Cl}$ strategy, capabilities and technologies are developed within the boundaries of the innovating firm and improved in order to reach the market and generate revenues. On the contrary, by implementing the Ol strategy the boundaries of the innovation funnel become permeable (Chesbrough, 2003) with R\&D projects a) jointly developed with other parties, b) developed by third parties before entering into the funnel or c) started by the company but leaving the funnel and further developed by third parties. The OI paradigm is conceived on the idea that companies are unable to hold in-house all the competencies they 
require, thus forcing them to open up their R\&D processes. In the last decade, inter-firm R\&D collaborations, strategic technologies alliances, joint development with universities and research groups, complex innovation networks and joint venturing investments have been incorporated into companies' technological strategies, since they give access to different knowledge bases and new resources.

Among the different $\mathrm{Ol}$ practices, we distinguish between equity alliances and non-equity alliances. Within equity alliances (i.e. joint ventures) companies agree to share capital, technology, human resources, risks and rewards and establish a new entity under shared control. From a knowledge perspective, equity alliances provide the highest level of partner interaction and are considered as the most effective means of knowledge transfer (Anand and Khanna, 2000). The joint creation of new knowledge requires high levels of resource commitment (e.g. capital, employees, time), equal motivation from both firms, and appropriate control mechanisms (Kogut, 1988). Conversely, non-equity alliances (i.e. R\&D collaborations) are characterized by lower resource commitment and give access to new knowledge bases, ideas and possibilities through the interaction with partners (Granovetter, 1973). Collaborations may differ in frequency and duration of the relationship and number of partners. Therefore, in an Ol system companies establish a complex inter-firm network of relationships with other organizations, in which each one teams up to generate new products and technologies (Dittrich and Duysters, 2007).

Many scholars studied the relationship between alliances and exploitative vs. explorative strategies. As to exploitation, intense collaborations with partners are required in order to achieve recurrent and trustful relationships (Krackhardt, 1992) and the creation of economies of scale. Companies pursuing an exploitation strategy will search for firms with similar technological capabilities: the collaboration needs time to build up and generates long-term benefits. Therefore, joint venturing strategies are mainly adopted in exploitative activities (Koza and Lewin, 1998), since companies need to establish strong ties with their partners and strong legal agreements. As of explorative strategies, they are pursued through alliances with partners with different capabilities, which give access to a different knowledge base. When exploring new technologies, firms need a more flexible form of alliance, since the result of the partnership is typified by more uncertainty and they need to abandon the alliance at any given moment (Duysters and De Man, 2003). Furthermore, explorative activities require a continuous scanning of new technological opportunities. As these opportunities often arise outside existing partners, partner turnover will be high (Dittrich and Duysters, 2007). For such reasons, non-equity alliances are strongly preferred in exploration strategies.
Given that collaborative R\&D activities are characterised by a larger field of application, the adoption of non-equity alliances is expected also in exploitation strategies. Actually, many scholars discovered that companies jointly develop new products in order to share the costs of exploiting a certain form of technology (Nakamura et al., 1996) and share risks and costs of innovation under growing technological complexity (Hung and Tang, 2008).Also, in industries featured by high market fragmentation companies with similar core business activities collaborate in standardization consortia, setting the standard for a particular technology (David and Steinmueller, 1995; Schmidt and Werle, 1998; Egyedi, 1999; Hawkins, 1999).

Even though, in the last decade, inter-firm R\&D alliances have become crucial for many companies belonging to industries characterized by intense R\&D activities, firms prefer to develop internally their core products, without collaborating or outsourcing. Actually, they can be produced better, faster, and more efficiently internally and alone than in collaboration with other companies. Firms protect their invention with intellectual property rights and exploit the results of their R\&D efforts in order to gain competitive advantage. Indeed, companies are rebuilding their internal R\&D organization: already twenty years ago, Archibugi and Pianta (1996) found that the importance of large inhouse laboratories was declining and the international dimension of the innovation process was growing. The increasing geographic distribution of R\&D activity is still an important phenomenon of globalization (Lahiri, 20l0): firms decentralize their R\&D activities and even more involve their subsidiaries in the technological development.

Even though centralized R\&D can generate technologies of greater impact (Argyres and Silverman, 2004), firms achieve exploitation through specialization, dividing themselves into various units to focus effort on specific products and geographic markets (Miller et al, 2007). The higher the complementarity of assets needed to bring products to market, the greater the divisionalisation of a company. Firms may geographically distribute their R\&D activities in order to share and allocate different technological domains (Nayyar and Kazanjian, 1993; Nerkar and Roberts, 2004). Further, divisionalisation might result from merger and acquisition activities: to avoid the loss of the capabilities of the new subsidiary, it is usually best to allow it to remain intact.

In addition to their local inputs, firms may source knowledge from distant units (Venaik et. al., 2005). Such inputs comprise new knowledge both created in the distant unit and sourced externally by the distant unit. According to Lahiri (2010), with increasing geographic distribution of R\&D activities, two issues may be defined: a) search costs increase, creating diseconomies of scale and b) transferring new knowledge from one unit to another becomes challenging. 


\section{Patent-based metrics for innovation strategies}

Patent data are the only formally and publicly verified outputs of inventive activities and are widely accepted as a measure of innovation. As suggested by Griliches (1990), data provided by patents contain information about the whole population of innovating firms, are standardized, stored for a long period of time and continuously updated. Patent statistics provide very specific and detailed information for evaluating inventive activities (Acs and Audretsch, 1989; Chakrabarti, 1991; Grupp, 1992). Furthermore, they are objective, since they have been processed and validated by patent examiners (Belderbos et al., 20I0). Unlike other measures of innovation (e.g. R\&D expenditures, number of R\&D personnel) which regard the input of R\&D activities, patent data focus on outputs of the inventive process, provide a valuable information about the effects of technological innovation and can be disaggregated to specific technological domains (Johnstone et al., 20I2). Since we aim at analysing the specific development activities carried out by companies at the technological domain level, we refer to patent data for studying the relationship between innovation and knowledge (Almeida and Kogut, 1999; Abraham and Moitra, 200I; Ahuja and Katila, 200I; Ahuja and Lampert, 200I). When scholars need to analyse knowledge domains, they focus on International Patent Classification (IPC) codes, which identify the belonging technological fields of an innovation. Actually, all patents are categorised into at least one IPC: such technological index operates like a keyword system (Graff, 2003). IPC codes are widely employed to investigate technological innovation strategies implemented by innovative firms: e.g., Sakata et al. (2009) studied IPC combinations in order to define the innovation position of Japanese companies, while Suzuki and Kodama (2004) described technological trajectories and technological diversification strategies by examining patent classification codes.

According to Belderbos et al. (2010), technological domains can be analysed in order to evaluate companies' exploitation vs. exploration strategies: a patent is considered as explorative if it is situated in a technological domain in which firm lacks of prior familiarity. Therefore, explorative innovation activities develop ideas situated in knowledge fields where the firm has not patented in the past five years, whilst exploitative ones refer to technologies developed in knowledge areas where the firm has patented technology in the previous five years. This assumption is in line with the idea that knowledge evolves rapidly and companies lose most of their technical experience if they abandon a technological field for five years (Argote, 1999; Ahuja and Lampert, 200 I; Fleming, 200 I; Hall et al., 2005; Leten et al., 2007), with competencies previously accumulated resulting obsolete and forcing them to re-explore such technological domain. Furthermore, when companies start to explore a new knowledge area, it remains relatively new until they accumulate experience in the search activity within it: such process requires time and resources, therefore, Belderbos et al. (2010) suggest that a technological field keeps its explorative status for a period of three consecutive years.

As regards to the management and organization of innovative activities, researchers focus on the assignee field disclosed in patent documents. When a firm develops inhouse a new technology, only one applicant is recorded in the patent application. On the contrary, a co-assignment is detected when two or more companies are involved in the development and make some contribution to the final invention, sharing the ownership of the innovation. Thus, copatents seem to be a relevant indicator for signalling the occurrence of Ol strategies (Chesbrough, 2006) and the number of patents deriving from collaborative projects can be considered as a proxy of Ol (Al-Ashaab et al., 20I I). Kim and Song (2007), using joint-patenting information, reported a growing $\mathrm{Ol}$ adoption.

\section{Methodological framework}

Starting from the literature review, we designed a patentbased framework with the aim of defining the relationship between technological fields and the management and organization of innovative processes. Therefore, our analysis is performed at the knowledge domain level, evaluating the different innovation strategies adopted for each technological field in which the firm is involved and cumulating each behaviour in order to define the overall innovation strategy pursued by a company. In this paper, we tested the framework on a sample of firms belonging to the bio-pharmaceutical (BP) and technology hardware \& equipment (THE) industries.

\section{Knowledge domains: exploration vs. exploitation and their relevance}

Regarding the operationalization of knowledge domains, we started from the one suggested by the scientific literature, analysing classification codes disclosed in patent documents. For each analysed company we downloaded patent data from PATSTAT database, considering patents applied in the investigated time interval and detecting their classification codes. Even though scholars examine technological fields through IPCs, in our framework we refer to the Cooperative Patent Classification (CPC) system, a nomenclature developed by the European Patent Office (EPO) and the United States Patent and Trademark Office (USPTO) in order to allow inventors to retrieve relevant prior art efficiently. Actually, such system combines the best practices of the two offices and was built starting from IPC classification; therefore, it may be considered as an evolution, 
since it is more specific and detailed: while the IPC has about 70,000 entries, the CPC has more than 250,000 , making it much more precise. The standardization allows us to analyse patent applications with both the EPO and the USPTO as a receiving office. Each CPC consists of a hierarchical symbol: the first letter defines the section, the two digits number denotes the class and the following letter identifies a subclass. The subclass is then followed by a one to three digits main group number, an oblique stroke and a number representing the subgroup. Unlike the operationalization applied in literature, we decided to cut the code and consider only the information before the stroke, since we believe that the operationalization of knowledge fields requires more generalization. For instance, Table I displays the hierarchical composition of the CPCs "H04W88/08" (i.e. access point devices) and "H04W88/I2" (i.e. access point controller devices) with our interpretation about the meaning to be assigned for research purposes.

Considering the entire code, we may study innovation at the component level, or rather at the maximum level of disaggregation. Since we aim at analysing innovative behaviours at the knowledge domain level, we require a higher level of aggregation and decide to cut the code at the stroke. For example, both CPCs, shown in Table I, belong to the same technological field (i.e. devices specially adapted for wireless communication networks): we hypothesize that different products or components may be developed within the same knowledge domain since competencies required in the innovative process are almost the same for both. Similarly, an excessive level of aggregation does not allow us to correctly identify the various capabilities that a company owns.
For each firm belonging to our sample, we detected from PATSTAT database the distinct CPCs disclosed in its patent applications. Each technological field is then labelled as exploitative or explorative and core or non-core.

As to the first label, we started from the operationalization suggested by Belderbos et al. (20I0):

- a knowledge domain is labelled as exploitative if the company filed patents in such technological field in the past five years, explorative otherwise;

- the technological field keeps its explorative status for a period of three consecutive years.

The five-year time span is based on the assumption that companies lose their previous experience if they abandon a specific technological domain, while the three-year one, used for evaluating the exploration, is necessary for companies to master a knowledge field before it is exploitable. Yet, such hypotheses do not seem to take into account the different features of the belonging industry of companies. For instance, in the BP sector the development of a new drug can take more than five years: the lack of patent applications in a specific technological domain in the previous five years does not imply the loss of knowledge, since an invention may be in the development phase. Hence, the experience interval should consider the higher time-to-prototype and, thus, should be increased. On the other side, in the THE industry the faster development pace and the shorter product life cycles force companies to continuously adapt their technical competencies, which may be considered obsolete in a time span lower than five years. Thus, in order to take into account industry-specific time spans, we adjusted the experience interval:

\begin{tabular}{|l|l|l|}
\hline Symbol & Classification & Meaning \\
\hline H & Electricity & Technological base \\
\hline H04 & Electrical communication systems & Technological sector \\
\hline H04W & Wireless communications networks & Technological segment \\
\hline H04W88 & $\begin{array}{l}\text { Devices specially adapted for wireless communication } \\
\text { networks }\end{array}$ & Knowledge domain (Technological field) \\
\hline $\begin{array}{l}\text { H04W88/08 } \\
\text { H04W88/I2 }\end{array}$ & $\begin{array}{l}\text { Access point devices } \\
\text { Access point controller devices }\end{array}$ & Products or components \\
\hline
\end{tabular}

Table I - Example of CPC hierarchical composition

ISSN: 07 I8-2724. (http://www.jotmi.org) 
- by adding 2 years for companies belonging to the $\mathrm{BP}$ industry, resulting in a seven-year time span;

- by removing 2 years for firms belonging to the THE one, considering a three-year time span.

Consequently, also the exploration interval is influenced by industry-specific characteristics (e.g. product complexity and development pace), with BP companies requiring more time to make a technological field exploitable and THE ones forced to speed up the process of familiarization with a new knowledge domain. Therefore, the exploration time span is set at:

- 4 years for companies in the BP industry;

- 2 years for THE firms.

Such operationalization is in line with the different market, product and industrial structures in which companies compete (Table 2). Without accounting for the time span adjustment factors, a comparison between the two industries may lead to inaccurate results. For this reason, we adjusted the values recognised in the scientific literature, which we consider as mean values applicable to all industries, rather than building them ex-novo.
In this paper, we analysed patents applied by companies in 20II. In order to label as exploitative or explorative each distinct CPC detected for every company, an examination of previous patent applications is required. Such study is limited by the experience interval defined for the belonging industry of the company. This range of time can be divided into two periods: the exploitation phase and the exploration one. Since the latter is previously defined and industryspecific, the former is fixed by difference. For instance, in the BP industry we analysed only patent applications from 2004 to 2010, having considered a seven-year time span for the of experience interval: the period of exploration is 4 years, then the time span for the exploitation is 3 . We are supposing that knowledge owned by the company before 2004 is not yet useful and available in $201 \mathrm{I}$, if afterwards it was not further accumulated and recombined, bringing to a new patent application. Since a CPC is labelled as exploitative if the company has already patented within the knowledge domain and has already trespassed the exploration phase, in the BP industry only technological fields for which at least a patent application is detected from 2004 to 2006 can be considered as exploitative in 201 I. However, if no patent was applied in such time interval, the technological field is still in the exploration phase: even though a patent application is detected from 2007 to 2010 , we assume that

\begin{tabular}{|l|l|l|}
\hline Industry characteristic & BP industry & THE industry \\
\hline Product development time & About I0-I2 years ' & About I-3 years \\
\hline Research activity & Basic research & Application science and engineering \\
\hline Regulations & Government regulations & $\begin{array}{l}\text { Industry standards and customer expecta- } \\
\text { tions }\end{array}$ \\
\hline Product & Integral nature & $\begin{array}{l}\text { Modularity of IT design, component-based } \\
\text { products }\end{array}$ \\
\hline Uncertainty of R\&D process & High & Medium-low \\
\hline Products and Intellectual & $\begin{array}{l}\text { Product covered by a small } \\
\text { number of patents }\end{array}$ & $\begin{array}{l}\text { Many patents to assemble intellectual prop- } \\
\text { erty rights for a single product }\end{array}$ \\
\hline Patenting strategy & $\begin{array}{l}\text { The company is the sole holder } \\
\text { of a drug patent }\end{array}$ & $\begin{array}{l}\text { The firm holds just a large enough percent- } \\
\text { age of the total relevant patents }\end{array}$ \\
\hline
\end{tabular}

Table 2 - Market, product and industrial structure for BP and THE companies

I Since bio-pharmaceutical companies have to apply the patent before a drug is subject to the evaluation of public health authorities, we assume that the invention is filed within 7 years from the beginning of the project, in line with the operationalization of the experience interval.

ISSN: 07 I8-2724. (http://www.jotmi.org) Journal of Technology Management \& Innovation @ Universidad Alberto Hurtado, Facultad de Economía y Negocios. 
in $201 \mathrm{I}$ within the knowledge domain the exploration phase is not yet complete (Figure I). Therefore, if no patent application reporting the specific CPC was found from 2004 to 2010, the CPC is new for the company, since the first patent has been applied in $20 \mathrm{II}$ and the knowledge domain is labelled as explorative. As to the THE industry, we considered only patents from 2008 to 2010 , and the CPC is labelled as exploitative if we find applications in 2008, explorative otherwise.

After having labelled a CPC as exploitative or explorative, a second label is assigned: core vs. non-core. Since not all the domains are relevant for the company, only some knowledge areas are strongly stressed and mostly contribute to the development of the core technology of current business activities. We aim at distinguishing between inventions in core technological fields and those in non-core ones and evaluating if the different relevance significantly affects the choice of management and organization of innovation strategies. In particular, each CPC is defined as core if it is declared in at least $10 \%$ of the patents filed in the experience interval, non-core otherwise: for instance, in the BP industry the relevance is estimated dividing the number of patents declaring the analysed CPC from 2004 to 2010 by the total amount of patent applications recorded from 2004 to 2010, considering only those reporting at least one CPC. This idea is based on the assumption that a technological field is core if its accumulation of knowledge in the experience interval generates a larger number of patent applications ${ }^{2}$.

\section{Management and organization of innovation}

In order to delineate how companies manage and organize their R\&D efforts, we refer to the assignee field disclosed in patent documents. Through the analysis of such a field, we are able to define which are the actors involved in the development of the invention.

The first step of the analysis regards the linkage between the companies of our sample and the PATSTAT applicant table. For each firm we searched in the assignee field both the name of the parent company and its subsidiaries, disclosed in the 2012 annual report, also taking into account the names of the units previously acquired or merged. The business units detected are then labelled as:

- local unit, if the country code disclosed in the applicant field is equal to that of the parent company;

- distant unit, if the country code is different;

- acquired company, if the subsidiary has been acquired by the parent company;

- merged company, if the subsidiary has been merged with the company group.

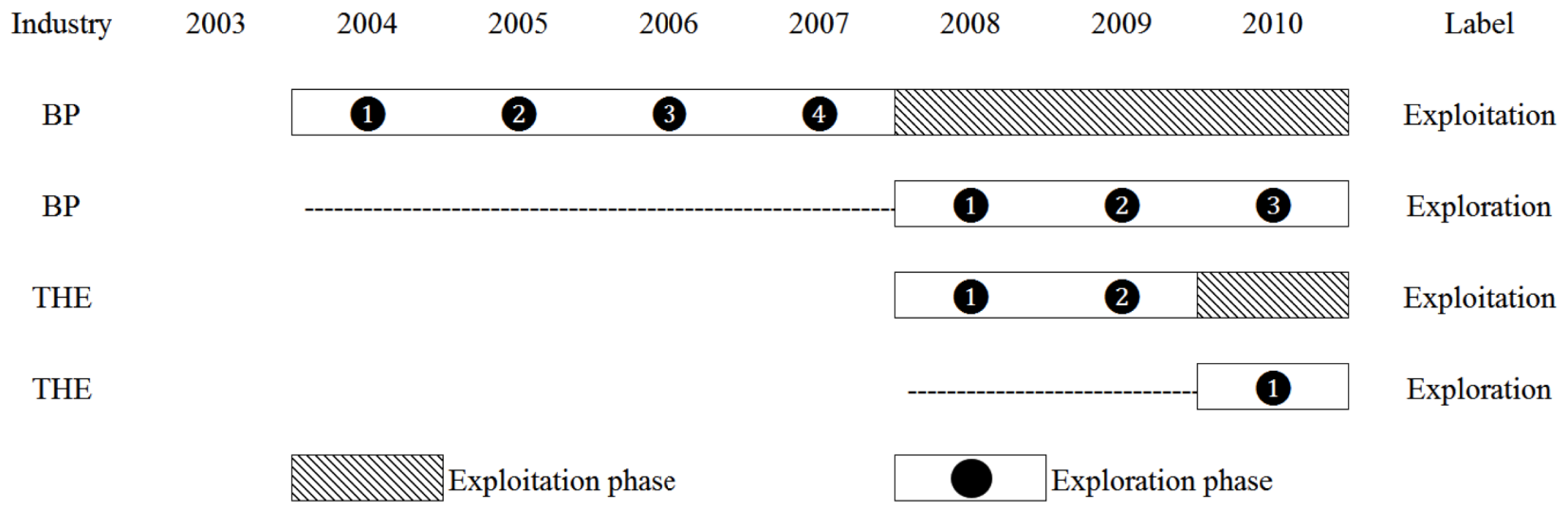

Figure I - Labelling of knowledge domains from patents filed in 20I I by BP and THE companies

2 The threshold of $10 \%$ is based on robustness tests. Indeed, by setting up the threshold to $15 \%$ for many companies no core knowledge domains were found, whilst reducing it to $5 \%$ the majority of technological fields is labelled as core, impeding a good distinction between core and non-core CPCs.

ISSN: 07 I8-2724. (http://www.jotmi.org) 
Regarding the country code field, it identifies the country of residence of the business. Given that for not all applicants a country code has been recorded ${ }^{3}$, we developed an algorithm in order to detect or correct its value:

- we searched for all the patents that report a specific applicant name;

- we found the country code more frequently assigned to such name;

- we assigned this country code to all the patents reporting that name;

- if no country code is reported for the specific applicant name, we assigned the country code of the parent company.

As to acquired and merged firms, we aim at identifying inventions developed after the acquisition/merger in order to understand whether the parent company allows them to remain intact and avoid the loss of their capabilities. Since the units are progressively integrated into the organizational structure of the company group, we hypothesize that their status of acquired or merged is preserved for a limited number of years. According to our operationalization regarding the experience period, we suppose that such status is retained for 7 years for BP companies and 4 years for THE ones. If they have already lost such status, the units are labelled as local or distant depending on their country code.

Furthermore, we performed a text search in 2010-2012 annual reports in order to find the names of joint ventures in which firms are involved, verifying whether in 201I the company group is still a shareholder of the equity alliance.

The second step of the analysis refers to the study of the companies disclosed in the applicant field. Since we left out any inventor from our framework, only firms are considered. We focus on the number of assignees recorded in patent documents in order to find information about the management and organization of the specific invention. Particularly:

3 This lack of information occurs in less than $20 \%$ of the analysed documents.
- if only one company is found, the patent is internally developed;

- if two or more companies were uncovered, but all belonging to the same company group, the patent is intra-group developed;

- if two or more different companies were found in the applicant field, we detect a joint patent among the analysed firm and third parties.

In addition, for the analysis of the innovative activities of the company we also considered patents with its joint venture as the assignee.

Since we aim at evaluating $\mathrm{Ol}$ adoption, we define five specific levels of openness that may be used for each knowledge domain, from the development of inventions within the local unit to alliances: actually, the different innovation strategies can be seen as a continuum from totally closed to totally open behaviours (Figure 2). At the first level (i.e. totally closed), firms manage internally their R\&D activities, focusing on the development within their local units. A first way of opening up the innovation boundaries is geographically distributing or decentralizing R\&D activities, outsourcing them to distant, acquired or merged units (i.e. second level). The third level requires the joint involvement in R\&D efforts of both local units and other ones. The next one is based on joint development activities among distant, acquired or merged units: the local unit is excluded from the innovative process. The last level (i.e. totally open) consists of technological development alliances with third parties: firms may be involved both in equity and non-equity alliances. Regarding non-equity alliances (i.e. joint development and R\&D collaboration) we separate joint patents into two categories, within and beyond the sample, with the aim of understanding whether companies in our sample prefer to collaborate in a network with other firms that we are studying or not. Thus, joint patents beyond the sample enclose joint development activities with companies outside our sample, research groups and universities. As to equity alliances (i.e. joint ventures) we consider both joint venturing activities with partners within and beyond our sample.

\begin{tabular}{|c|c|c|}
\hline \multirow[t]{6}{*}{ CLOSED } & local unit development & Level I \\
\hline & distant, acquired or merged unit development & Level 2 \\
\hline & intra-group development with local unit & Level 3 \\
\hline & intra-group development without local unit & Level 4 \\
\hline & joint development within the sample & \\
\hline & joint development beyond the sample & Level 3 \\
\hline OFEN & joint venture development & \\
\hline
\end{tabular}

Figure 2 - Innovation strategies as a continuum from totally closed to totally open behaviours

ISSN: 07 I8-2724. (http://www.jotmi.org) 


\section{The patent-based framework}

Patent data are the only formally and publicly verified outputs of inventive activities, are widely accepted as a measure of innovation and are used as a means of appropriation of innovation in both BP and THE industries (Pavitt, 1984). Therefore, we developed a patent-based framework in order to understand which factors affect the choice of $\mathrm{Ol}$ adoption in such sectors, defining the relationship with the relevance of the technological domain and the exploitation vs. exploration strategies. While Ol strategies can be detected through the assignee field of a patent document, relevance and exploitation vs. exploration strategies can be defined through the study of CPCs. Since our analysis is performed at the knowledge domain level, we started detecting the distinct CPCs disclosed in patents filed by a company in 20I I, adding also CPCs from its joint ventures. Patent documents without CPC codes are excluded from the analysis. Even though we consider CPCs within equity alliances, the CPC labelling methodology previously described does not account for the impact of the joint venture in the evaluation of relevance and exploitation vs. exploration strategy, since the equity alliance preserves its specific and different organizational structure and involves other shareholders. For instance, a CPC labelled as noncore for the firm may be core for its joint venture: this assumption allows us to understand the reason why the company enters into an equity alliance with third parties.

Furthermore, for each CPC we search for patents applied in $20 \mathrm{I}$ I, in which the knowledge domain is recorded, and study the assignee field in order to define the level of openness of the invention, as previously described. Given that a CPC can be detected in more than one document, different levels of openness can be found in the same technological field, i.e. the firm may exploit a knowledge domain both within the local unit and in R\&D collaboration with external partners. The individual information collected for each technological field is used to study the overall behaviour of a firm, summing the results obtained from all the CPCs. Therefore, our framework can evaluate the weight of a single label on the overall innovation strategy through a share indicator. For instance:

- the core share is the share of patenting activities within CPCs labelled as core compared to the total amount of patenting activities in which the firm is involved in 2011;

- the exploration share is the share of explorative activities (i.e. activities within CPCs labelled as explorative) compared to the total amount of patent applications in 2011 .
Obviously, we may mix the two labels and evaluate, for example, the weight of core explorative activities. Therefore, adding the information about the organization of innovative processes, we analyse how companies manage their R\&D efforts, i.e. the weight of each level of openness on the total amount of patent applications. Otherwise, we may mix such OI levels with the relevance and exploitation vs. exploration labels, obtaining 20 share indicators (e.g. noncore explorative activities within the local unit).

Our framework supports us in identifying firms' innovation strategies in a specific time interval and provides a useful instrument for benchmarking (i.e. firm-level analysis). Further, by selecting a sample of companies and cumulating the results obtained for each one, the framework also provides information about technological innovation in specific industries, enabling us to perform an industry-level analysis.

In Appendix I, we provide an example of our framework application to patent documents filed by Biotie Therapies Corp. in 201 I. Limitations pertaining to both the use of patent data and our operationalization are outlined in discussions.

\section{Findings}

The devised framework was applied to a sample of 240 R\&D intense companies from BP and THE industries (Appendix 2 ), ranked by their investment in R\&D, according to The 2012 EU Industrial R\&D Investment Scoreboard (JRC, 20I2), excluding firms whose 2012 annual reports were not available on the internet and those for which the list of subsidiaries was not found in such documents. In detail, the sample consists of 103 BP companies and I37 THE ones. We downloaded from PATSTAT database about 20,000 patent documents filed in 2011 by BP companies and about 80,000 applied in $201 \mathrm{I}$ from THE ones, performing an industry-level analysis for each sector. Then, we compared the results in order to detect differences in the adoption of Ol strategies between the two industries. In addition, more than 4,000 patent applications filed in $201 \mathrm{I}$ by 36 joint ventures, owned by companies belonging to our sample, are considered in the analysis. Since a study of innovative activities within the experience period is required in order to label knowledge domains, we also downloaded about 230,000 patents filed by BP companies from 2004 to 2010 and about 300,000 applied by THE ones from 2008 to 2010 . Each industry-level analysis is performed cumulating the results obtained for each company within the belonging sector. 


\section{Knowledge domains}

Table 3 shows the results of labelling activities on knowledge domains which are obtained performing an industry-level analysis on companies belonging to our sample.

\begin{tabular}{|l|l|l|l|l|}
\hline Industry & Core & Non-core & Exploitation & Exploration \\
\hline BP & $25.79 \%$ & $74.21 \%$ & $91.69 \%$ & $8.31 \%$ \\
\hline THE & $18.39 \%$ & $81.61 \%$ & $89.68 \%$ & $10.32 \%$ \\
\hline
\end{tabular}

Table 3 - Relevance and exploitation vs. exploration shares for BP and THE companies

BP firms mostly tend to concentrate patenting activity within a familiar and crucial technological field (i.e. core knowledge domain), whilst in the THE industry the capability to recombine and integrate pieces of knowledge belonging to different knowledge domains is primarily critical and leads to a higher breadth of technological fields involved in the development, thus, reducing the average relevance of each CPC. Since the production in the THE industry often requires electrical and software engineering competencies and the integration with a variety of components, companies may also require knowledge of multiple technologies to work effectively with their suppliers (Brusoni et al., 200I). On the contrary, BP companies are involved in a very risky innovative process that is extremely expensive, takes a very long time and has a high failure rate (Mazzucato and Tancioni, 2012). Therefore, they are forced to conduct a "guided search", typified by more scale economies and pathdependency (Gambardella, 1995), and concentrate their activities towards skills that are essential for their survival.
In regards to exploitative vs. explorative behaviours, a similar strategy is detected between the industries: exploitation strategies are strongly preferred, covering about $90 \%$ of innovative activities. Even though companies need to combine both exploitative and explorative activities to effectively improve their survival chances and performance, the heritage of routines adopted in the past conditions learning opportunities. Companies tend to develop new knowledge in domains in which they already possess competencies (Teece, 1986), thus preferring to exploit a technological domain rather than exploring a new one. When they understand the need of a new body of knowledge they start to explore new knowledge domains, preferring those that are close to ones they currently have at their disposal (Dosi, 1982).

Since we assign two different labels to each CPC, we may examine the combination of relevance and exploitation vs. exploration strategy. Results displayed in Table 4 confirm the similar approach adopted by both BP and THE companies in managing explorative activities. As a consequence of the previous findings, different behaviours are detected in exploitation strategies, with BP firms mostly stressing core technological domains. Nevertheless, both industries are characterised by non-core exploitative activities, which cover more than one-half of innovative processes. Regarding the core explorative ones, they are negligible and challenging: actually, they can be considered as a signal of switching strategy to new knowledge domains which requires a complete rescheduling of innovative processes and relevant changes in the organization of R\&D activities, thus, resulting usually non-viable.

\begin{tabular}{|l|l|l|l|l|l|}
\hline Industry & Core exploitation & Core exploration & Non-core exploitation & Non-core exploration & Total \\
\hline BP & $25.64 \%$ & $0.15 \%$ & $66.05 \%$ & $8.17 \%$ & $100.00 \%$ \\
\hline THE & $18.34 \%$ & $0.05 \%$ & $71.33 \%$ & $10.27 \%$ & $100.00 \%$ \\
\hline
\end{tabular}

Table 4 - Shares of knowledge domain labels for BP and THE companies

\begin{tabular}{|l|l|l|l|l|l|l|l|l|}
\hline Industry & Level I & Level 2 & Level 3 & Level 4 & $\begin{array}{l}\text { Level 5 } \\
\text { (within) }\end{array}$ & $\begin{array}{l}\text { Level 5 } \\
\text { (beyond) }\end{array}$ & $\begin{array}{l}\text { Level 5 } \\
\text { (joint venture) }\end{array}$ & Total \\
\hline BP & $57.68 \%$ & $32.65 \%$ & $1.53 \%$ & $0.59 \%$ & $0.90 \%$ & $6.54 \%$ & $0.11 \%$ & $100.00 \%$ \\
\hline THE & $85.35 \%$ & $7.20 \%$ & $0.36 \%$ & $0.25 \%$ & $0.02 \%$ & $1.20 \%$ & $5.62 \%$ & $100.00 \%$ \\
\hline
\end{tabular}

Table 5 - Shares of the five levels of Ol adoption for BP and THE companies

ISSN: 07I 8-2724. (http://www.jotmi.org)

Journal of Technology Management \& Innovation (c) Universidad Alberto Hurtado, Facultad de Economía y Negocios. 


\section{Management and organization of innovation}

The innovation management, and the related organizational choices, is summarised defining five levels of Ol adoption, from the totally closed strategy (i.e. level I) to the totally open one (i.e. level 5). Since we need to stress the difference in the adoption of technological innovation alliances among companies, we separate the fifth level into three categories: non-equity alliances within the sample, non-equity alliances beyond the sample and equity alliances. Table 5 presents the different behaviours detected in the two industries regarding the shares of each OI level.

The totally closed approach is the strategy more frequently adopted and, in both industries, covers more than one-half of innovative activities, more markedly in THE one where companies choose such strategy to speed up their R\&D processes, being development pace faster and product life cycles shorter.

The second level of openness is a characteristic of the BP industry, with companies outsourcing R\&D activities to distant, acquired and merged units. Nevertheless, the share of innovative activities at the level 2 is also significant for THE firms, being such outsourcing strategy the second mostly adopted. Rausser (1999) suggested that in the BP industry the range of technologies necessary to market a new product is rarely controlled by a single firm. Therefore, companies employ merger and acquisition strategies in order to acquire external sources: the employees' embedded knowledge of merged and acquired firms will remain intact if the innovative effort is completely owned by the new unit. As to distant units, a firm belonging to the BP industry seems to better recognise the high value of specialized competencies developed and accumulated by them, establishing geographic divisions to collocate different knowledge domains. We believe that the result is affected by the integral nature of innovation that features the BP industry, which forces firms to completely outsource relevant shares of risky and expensive development activities: since they take a very long time, the parent company is unable to hold in house every project.

Regarding the third and the fourth level (i.e. intra-group development activities), their share covers a limited amount of innovative activities, with BP companies being more inclined to adopt such a strategy. The joint development requires intra-organizational linkages and the transfer of different capabilities among units. Even though the potential for opportunism is great, there are significant challenges in transferring knowledge from one unit to another: for instance, such knowledge may be not completely understood by the receiving unit (Lahiri, 20I0).
As to technological strategic alliances detected at the level 5 , they represent the third most adopted innovation strategy, covering the $7.55 \%$ of R\&D activities in the BP industry and the $6.84 \%$ in the THE one. Significant differences were discovered between the two industries: equity alliances are strongly preferred by THE companies, while non-equity ones characterize BP firms. In the THE industry, firms invest in joint ventures in order to gain entrance into foreign markets and share complementary capabilities and resources, while R\&D collaborations cover a smaller share of innovative activities and are pursued with other companies which manufacture parts, components and products that are incorporated into firms' products or with external partners in order to set the standard for a particular technology. Regarding BP companies, since no single firm possesses all the knowledge, skills and techniques required (Powell et al., 1996), the collaboration results from the need for complementary expertise. The BP industry is characterized by the highest rate of joint patenting activities (Kim and Song, 2007) and Ol is seen not only as an innovation strategy, but as the very core business model for many companies, especially for biotech ones: as a matter of fact, most of them do not sell products, but rather enter into collaboration agreements with other BP companies. Another interesting result found in the BP industry is that joint patents within the sample, if compared with the aggregate share of non-equity alliances (i.e. $7.44 \%$ ), cover about the $12 \%$ of the joint development activities, signalling the relevance of the network of technological alliances among the 103 firms belonging to our sample. As to joint venturing, in the BP industry such strategy is negligible, since companies prefer technology acquisition modes that require lower resource commitment (i.e. R\&D collaboration). Furthermore, equity alliances are usual among firms with larger size and similar technological relevance (Hung and Tang, 2008), but in BP industry alliances are mainly carried out among small biotech companies and large pharmaceutical ones.

\section{Innovation strategies and openness level}

In order to point out the relationship between innovation strategies at the knowledge domain level, synthesized by the relevance of the technological fields and the exploitative vs. explorative activities, and Ol adoption, which spreads from the totally closed technological development to the totally open one, we mix three labels (i.e. relevance, exploitation vs. exploration and $\mathrm{OI}$ level) and analyse, after a multidimensional perspective, how companies manage their R\&D efforts. Tables 6 and 7 exhibit the distribution of $\mathrm{Ol}$ activities for each innovation strategy in BP and THE industries, supporting us in understanding the contribution of each OI mode on the overall innovation strategy pursued by the firms belonging to our sample. In both industries, the core exploitation strategy is pursued with low levels of $\mathrm{Ol}$ 
activities, while in the BP one the challenge of creating new relevant capabilities in which firms lack of prior technical experience (i.e. core exploration) is undertaken through R\&D collaboration with external partners, as suggested by many scholars. Actually, about one-third of core explorative activities is jointly developed with third parties, therefore for BP companies non-equity alliances significantly affect the business models. As to non-core innovative activities, they are developed similarly to core exploitation ones, since the first two levels cover about $90 \%$ of R\&D efforts.

Tables 6 and 7 support us in evaluating which Ol activities mostly contribute to the four technological strategies we considered. In our study, we are also interested in understanding the reason why companies open up their R\&D processes and which innovative activities are pursued within each Ol level, besides their impact on the overall innovation strategy. The results, reported in Tables 8 and 9 , show that:

- the level I is strongly preferred in both industries for exploitative activities;

- at the second level firms concentrate their R\&D efforts in exploitative activities, even though THE companies also outsource to distant, acquired and merged units the exploration of non-core knowledge domains;
- the levels 3 and 4 are preferred for non-core exploitative activities;

- non-equity alliances among companies belonging to our samples are required in order to exploit technological fields, with BP firms more frequently concentrating on relevant ones;

- joint development activities with universities, research groups and companies outside the samples are carried out in non-core innovation activities in both industries, with a preponderance of exploitative ones;

- joint ventures mainly operate in exploitation processes, with THE firms also conducting explorative activities in non-core technological fields.

\begin{tabular}{|l|l|l|l|l|l|l|l|l|}
\hline & Level I & Level 2 & Level 3 & Level 4 & $\begin{array}{l}\text { Level 5 } \\
\text { (within) }\end{array}$ & $\begin{array}{l}\text { Level 5 } \\
\text { (beyond) }\end{array}$ & $\begin{array}{l}\text { Level 5 } \\
\text { (joint venture) }\end{array}$ & $\begin{array}{l}\text { Total } \\
\text { BP }\end{array}$ \\
\hline Core exploitation & $67.22 \%$ & $24.10 \%$ & $0.76 \%$ & $0.58 \%$ & $0.95 \%$ & $6.15 \%$ & $0.24 \%$ & $100.00 \%$ \\
\hline Core exploration & $48.78 \%$ & $15.85 \%$ & $0.00 \%$ & $0.00 \%$ & $2.44 \%$ & $32.93 \%$ & $0.00 \%$ & $100.00 \%$ \\
\hline Non-core exploitation & $54.77 \%$ & $35.29 \%$ & $1.83 \%$ & $0.49 \%$ & $0.85 \%$ & $6.69 \%$ & $0.07 \%$ & $100.00 \%$ \\
\hline Non-core exploration & $51.41 \%$ & $38.36 \%$ & $1.55 \%$ & $1.44 \%$ & $1.16 \%$ & $6.04 \%$ & $0.04 \%$ & $100.00 \%$ \\
\hline
\end{tabular}

Table 6 - Share of Ol activities in BP companies for each technological strategy

\begin{tabular}{|l|l|l|l|l|l|l|l|l|}
\hline Label & Level I & Level 2 & Level 3 & Level 4 & $\begin{array}{l}\text { Level 5 } \\
\text { (within) }\end{array}$ & $\begin{array}{l}\text { Level 5 } \\
\text { (beyond) }\end{array}$ & $\begin{array}{l}\text { Level 5 } \\
\text { (joint venture) }\end{array}$ & $\begin{array}{l}\text { Total } \\
\text { THE }\end{array}$ \\
\hline Core exploitation & $87.44 \%$ & $5.84 \%$ & $0.20 \%$ & $0.11 \%$ & $0.01 \%$ & $0.91 \%$ & $5.49 \%$ & $100.00 \%$ \\
\hline Core exploration & $85.53 \%$ & $14.47 \%$ & $0.00 \%$ & $0.00 \%$ & $0.00 \%$ & $0.00 \%$ & $0.00 \%$ & $100.00 \%$ \\
\hline Non-core exploitation & $86.52 \%$ & $6.78 \%$ & $0.40 \%$ & $0.29 \%$ & $0.03 \%$ & $1.21 \%$ & $4.79 \%$ & $100.00 \%$ \\
\hline Non-core exploration & $73.49 \%$ & $12.53 \%$ & $0.40 \%$ & $0.21 \%$ & $0.01 \%$ & $1.66 \%$ & $11.72 \%$ & $100.00 \%$ \\
\hline
\end{tabular}

Table 7 - Share of Ol activities in THE companies for each technological strategy

ISSN: 07 I8-2724. (http://www.jotmi.org) 


\begin{tabular}{|l|l|l|l|l|l|l|l|}
\hline Label & Level I & Level 2 & Level 3 & Level 4 & $\begin{array}{l}\text { Level 5 } \\
\text { (within) }\end{array}$ & $\begin{array}{l}\text { Level 5 } \\
\text { (beyond) }\end{array}$ & $\begin{array}{l}\text { Level 5 } \\
\text { (joint venture) }\end{array}$ \\
\hline Core exploitation & $29.88 \%$ & $18.93 \%$ & $12.79 \%$ & $25.38 \%$ & $27.08 \%$ & $24.11 \%$ & $54.84 \%$ \\
\hline Core exploration & $0.12 \%$ & $0.07 \%$ & $0.00 \%$ & $0.00 \%$ & $0.40 \%$ & $0.74 \%$ & $0.00 \%$ \\
\hline Non-core exploitation & $62.72 \%$ & $71.40 \%$ & $78.95 \%$ & $54.68 \%$ & $62.06 \%$ & $67.61 \%$ & $41.94 \%$ \\
\hline Non-core exploration & $7.28 \%$ & $9.60 \%$ & $8.26 \%$ & $19.94 \%$ & $10.47 \%$ & $7.55 \%$ & $3.23 \%$ \\
\hline Total & $100.00 \%$ & $100.00 \%$ & $100.00 \%$ & $100.00 \%$ & $100.00 \%$ & $100.00 \%$ & $100.00 \%$ \\
\hline
\end{tabular}

Table 8 - Share of technological strategies within each OI level in the BP industry

\begin{tabular}{|l|l|l|l|l|l|l|l|}
\hline & Level I & Level 2 & Level 3 & Level 4 & $\begin{array}{l}\text { Level 5 } \\
\text { (within) }\end{array}$ & $\begin{array}{l}\text { Level 5 } \\
\text { (beyond) }\end{array}$ & $\begin{array}{l}\text { Level 5 } \\
\text { (joint venture) }\end{array}$ \\
\hline Core exploitation & $18.79 \%$ & $14.88 \%$ & $10.17 \%$ & $8.52 \%$ & $6.67 \%$ & $13.87 \%$ & $17.89 \%$ \\
\hline Core exploration & $0.05 \%$ & $0.10 \%$ & $0.00 \%$ & $0.00 \%$ & $0.00 \%$ & $0.00 \%$ & $0.00 \%$ \\
\hline Non-core exploitation & $72.31 \%$ & $67.14 \%$ & $78.53 \%$ & $82.97 \%$ & $90.00 \%$ & $71.92 \%$ & $60.71 \%$ \\
\hline Non-core exploration & $8.85 \%$ & $17.88 \%$ & $11.30 \%$ & $8.52 \%$ & $3.33 \%$ & $14.21 \%$ & $21.40 \%$ \\
\hline Total & $100.00 \%$ & $100.00 \%$ & $100.00 \%$ & $100.00 \%$ & $100.00 \%$ & $100.00 \%$ & $100.00 \%$ \\
\hline
\end{tabular}

Table 9 - Share of technological strategies within each OI level in the THE industry

Regarding innovative processes involving distant units (i.e. levels from 2 to 4 ) a high level of non-core exploitation was expected, since the divisionalisation is required in order to focus R\&D efforts on specific products or geographic markets, which may be less relevant if compared with the overall business of the company group. As to non-equity alliances, consistently with literature, BP companies rely on such open strategy in order to explore new knowledge domains (Table 6), even though at the specific Ol level joint patents within the sample are characterised by higher shares of exploitative activities (Table 8). With regard to the THE firms, non-equity alliances do not significantly affect their innovative processes (Table 7).

A final remark has to be done as to equity alliances: in line with the scientific literature, we found that joint venturing strategies are mainly adopted in exploitative activities. Such approach is particularly confirmed in the BP industry, where exploitation affects both core and non-core innovative processes, whereas in the THE one a more complex strategy is detected: equity alliances are useful to develop inventions in less relevant knowledge domains. This emphasizes that companies share their secondary competencies (e.g. electrical and software engineering ones) or try to integrate their components with those of their partners, creating new markets and businesses. This search for complementary assets may also lead to explorative activities, which cover about one-fifth of R\&D efforts conducted within the joint venture.

\section{Discussion}

This paper contributes to the debate on Ol by suggesting a framework for analysing in detail which $\mathrm{Ol}$ activities are pursued, their impact on the overall innovation strategy, and the relationship with the relevance and the exploitative vs. explorative status of the technological domains owned by companies. Ol modes are divided into five levels, from the totally close strategy to the totally open one. Regarding the impact of strategic technological alliances on companies' innovation strategy, our results are in line with the scientific literature, with non-equity alliances, significantly affecting firms' business models, preferred in explorative activities and equity alliances in exploitative ones (Dittrich and Duysters, 2007). By studying exploitative vs. explorative activities, we suggest a methodology to evaluate the share of each strategy on the overall innovation strategy pursued by companies, confirming that exploitation strongly prevails on exploration (Dosi, 1982; Teece, 1986). Even though they are ambidextrous and can coexist inside the firm (March, 1991; Levinthal and March, 1993; March, 1996; Tushman and O'Reilly, 1996; Benner and Tushman, 2003; He and Wong, 2004; March, 2006), within a specific knowledge domain they cannot (Burgelman, 2002; Gupta et al., 2006). We also aim at contributing to the current innovation literature by examining the relevance of the technological domains. Each Ol level shows different shares of core and noncore innovative activities, e.g. an higher share of non-core ones is detected in levels from 2 to 4 , suggesting that firms 
mostly concentrate within local units (i.e. level I) their R\&D efforts in core processes. The framework also evaluates the relationship between relevance of knowledge domains and $\mathrm{OI}$ levels. Interesting results were found regarding R\&D activities pursued with external partners: for instance, joint ventures are strongly characterised by non-core processes in the THE industry, while in the BP one we recorded a higher share of innovative activities involving relevant technological fields.

We provide a methodology investigating OI strategies on the basis of the study of patent applications, by using information disclosed in data recorded in PATSTAT database. The advantages in employing patent data in our study are:

- they are a direct outcome of R\&D efforts, and of those inventions which firms expect may have a commercial impact and provide benefits that outweigh costs for obtaining intellectual property protection;

- they contain highly detailed information on content and ownership of patented technology;

- they cover a broad range of technologies.

Yet, some limitations regarding the use of patent data can be underlined for the work. Firstly, the use of patenting information as a proxy of technological activities might underestimate the phenomenon, since not all R\&D efforts will result in an application for a patent. Secondly, the use of patent data for investigating the adoption of Ol could be questionable, since not all R\&D collaborations can be captured by co-patenting activities (Hagedoorn et al., 2003); this may lead to the underestimation of Ol activities. Furthermore, not all technological inventions are patented and patent propensities vary across firms and industries, even though in sectors characterized by intense R\&D efforts, like BP and THE ones, patents are used as a means of appropriation of innovation (Pavitt, 1984). This leads to the consideration that our framework may not be useful for analysing innovation in all industries.

Other limitations are related to the operationalization of patent information stored in PATSTAT database. For instance:

- usually patents belong to a specific patent family which includes all the document filed in different patent offices, therefore, the family size of an innovation affects the innovative behaviours we detected;

- typing mistakes in person fields impede the linking between applicants and companies belonging to the sample, thus, some patent applications may have been missed;

- some documents are excluded from the analysis since they did not contain a CPC code;

- the results found in the analysis are affected by our definition of core and non-core technological fields - CPCs are considered core if they are declared in at least $10 \%$ of the patents filed in the experience period - and, in particular, by the decision of cutting CPCs without considering the subgroup number, in order to avoid excessive detail on the definition of the knowledge domains owned by companies;

- the lack of information about the applicants' country code field in about the $20 \%$ of the analysed patents forced us in developing an algorithm in order to detect or correct such a field.

Unlike other scholars analysing exploitation vs. exploration activities, we decided to modify the value of the experience period, since we believe that it is industry-specific. By considering a time span adjustment factor we take into account the different features of the belonging sector of companies and such assumption affects the labelling activity of each technological field owned by firms. This consideration suggests a deepening of the operationalization of knowledge domain level variables, e.g. building a statistical model in order to define for each industry the proper time spans, rather than identifying them through the analysis of the characteristics of R\&D processes.

\section{Conclusions}

We aim at contributing to the current literature on innovation management by providing a patent-based framework which describes how companies manage their innovative activities at the knowledge domain level, stressing the impact of Ol strategies and analysing the reason why firms open up their innovation boundaries. We draw on objective data gathered from PATSTAT database and employ variables already acknowledged and operationalized by scholars.

An industry-level analysis on a sample of 240 R\&D intense companies from BP and THE industries was performed, considering patent applications in 20II, validating both the framework applicability and its explicative power and usefulness. Many differences in the adoption of $\mathrm{Ol}$ strategies were found, in line with the scientific literature and the characteristics of each industry.

The paper addresses the need for operative, practical instruments, which can help managers to monitor and control their innovative activities. Given the availability and objectivity of patent documents, studying innovation through the analysis of patent data can help decisionmakers to assess the status of their own strategies and compare it over time and space, also allowing the benchmarking with competitors. 
Further research will be addressed to widening our sample of investigation, by analysing different industries and making comparisons among innovation strategies of companies with different features. In order to evaluate the overall impact of Ol adoption, we plan to enforce our framework introducing both other inbound strategies (e.g. separate acquisition of patents, patent portfolio belonging to acquired or merged companies) and outbound ones (e.g. separate disposal of patents). Also, starting from the methodology designed by Michelino et al. (20I4a), correlations between strategic behaviours, detected through our framework, context features (e.g. firm's age and dimension) and financial performances are under investigation. Finally, we are trying to match the openness indicator provided by this framework with the openness ratios assessing the pecuniary dimension of OI (Michelino et al., 20|4b).

\section{About the Authors}

Francesca Michelino is an Adjunct Professor of Marketing and Supply Chain Management at the University of Salerno, Italy. Her research interests include: IT organisation and supply chain management, innovation management and open innovation.

Antonello Cammarano is a PhD student in Engineering and Economics of Innovation at the University of Salerno, Italy. His research interests concern open innovation and patent data analysis.

Emilia Lamberti is a PhD student in Enterprise Engineering at the University of Rome "Tor Vergata", Italy. Her research interests pertain to open innovation and innovation measurement.

Mauro Caputo is a Full Professor of Innovation and Technology Management at the University of Salerno, Italy. His research interests comprise: logistics and physical distribution, IT organisation and supply chain management, innovation management and open innovation.

\section{References}

ABRAHAM, B.P., Moitra, S.D. (200I). Innovation assessment through patent analysis. Technovation, 21 (4), 245-252. doi: http://dx.doi.org/I0.1016/s0166-4972(00)00040-7

ACS, Z.J., Audretsch, D.B. (1989). Patents as a measure of innovative activity. Kyklos, 42(2), I7I- /80. doi: http://dx.doi. org/I0.1 I I I/j.1467-6435.1989.tb00I86.x

AGRYRES, N.S., Silverman, B.S. (2004). R\&D, organization structure and the development of corporate technological knowledge. Strategic Management Journal, 25(89), 929-958. doi: http://dx.doi.org//0.1002/smj.387

AHUJA, G., Katila, R. (200I). Technological acquisitions and the innovation performance of acquiring firms: a longitudinal study. Strategic Management Journal, 22(3), 197-220. doi: http://dx.doi.org//0.1002/smj.157

AHUJA, G., Lampert, C.M. (200I). Entrepreneurship in the large corporation: a longitudinal study of how established firms create breakthrough inventions. Strategic Management Journal, 22(6), 52I-543. doi: http://dx.doi.org//0.1002/ smj. 176

AL-ASHAAB, A., Flores, M., Doultsinou, A., Magyar, A. (20I I). $A$ balanced scorecard for measuring the impact of industryuniversity collaboration. Production Planning \& Control, 22(5-6), 554-570. doi: http://dx.doi.org//0.1080/09537287.2 010.536626

ALMEIDA, P., Kogut, B. (1999). Localization of knowledge and the mobility of engineers in regional networks. Management Science, 45(7), 905-9/7. doi: http://dx.doi.org//0.1287/ mnsc.45.7.905

ANAND, B.N., Khanna, T. (2000). Do firms learn to create value? The case of alliances. Strategic Management Journal, 21 (3), 295-315. doi: http://dx.doi.org//0.1002/(sici)10970266(200003)21:3\%3C295::aid-smj91\%3E3.3.co;2-f

ARCHIBUGI, D., Pianta, M. (1996). Measuring technological change through patents and innovation surveys.Technovation, 16 (9), 45I-468. doi: http://dx.doi.org/I0.1016/0I66$4972(96) 0003$ I-4

ARGOTE, L. (1999). Organizational learning: creating, retaining and transferring knowledge. Kluwer Academic Publishers, Boston. 
BELDERBOS, R., Faems, D., Leten, B. and Van Looy, B. (20I0). Technological activities and their impact on the financial performance of the firm: exploitation and exploration within and between firms. Journal of Product Innovation Management, 27(6), 869-882. doi: http://dx.doi.org/I0.1 I I I/ j.1540-5885.2010.00757.x

BENNER, M.J., Tushman, M. (2002). Process management and technological innovation: a longitudinal study of the photography and paint industries. Administrative Science Quarterly, 47(4), 676-706. Doi: http://dx.doi. org/ $10.2307 / 30949 \mid 3$

BENNER, M.J., Tushman, M. (2003). Exploitation, exploration, and process management: the productivity dilemma revisited. Academy of Management Review, 28(2), 238-256. doi: http:// dx.doi.org/I0.5465/amr.2003.94I6096

BRUSONI, S., Prencipe, A., Pavitt, K. (200I). Knowledge, specialization, organizational coupling, and the boundaries of the firm: why do firms know more than they make?. Administrative Science Quarterly, 46(4), 597-62I. doi: http:// dx.doi.org// 0.2307/3094825

BURGELMAN, R.A. (2002). Strategy as vector and the inertia of coevolutionary lock-in. Administrative Science Quarterly, 47(2), 325-357. doi: http://dx.doi.org//0.2307/3094808

CHAKRABARTI,A.K.(I99I).Competition in high technology: analysis of patents of US, Japan, UK, West Germany, and Canada. IEEE Transactions of Engineering Management, 38(I), 78-84. doi: http://dx.doi.org// 0.1 / 09//7.65763

CHANG, S.J. (1996). An evolutionary perspective on diversification and corporate restructuring: entry, exit, and economic performance during 1981-89. Strategic Management Journal, 17(8), 587-6II. doi: http://dx.doi. org/ I 0.1002/(sici) 1097-0266(1996/0) 17:8\%3C587::aidsmj834\%3E3.0.co;2-I

CHESBROUGH, H. (2003). Open Innovation: the new imperative for creating and profiting from technology. Harvard Business School Press, Boston.

CHESBROUGH, H.W. (2006). Open business models: how to thrive in the new innovation landscape, Harvard Business School Press, Boston.

CHRISTENSEN, C.M., Overdof, M. (2000). Meeting the challenge of disruptive change. Harward Business Review, 78(2), 66-76.
COHEN, W.M., Levinthal, D.A. (1990). Absorptive capacity: a new perspective on learning and innovation. Administrative Science Quarterly, 35(I), 128-152. doi: http://dx.doi. org/10.2307/2393553

DAVID, P.A., Steinmueller, W.E. (1995). Economics of compatibility standards and competition in telecommunication networks. Information Economics and Policy, 6(3-4), 217-242. doi: http://dx.doi.org/10.1016/01676245(94)90003-5

DITTRICH, K., Duysters, G. (2007). Networking as a means to strategy change: the case of open innovation. Journal of Product and Innovation Management, 24(6), 510-521. doi: http://dx.doi.org/I0.I I I I/j.1540-5885.2007.00268.x

DOSI, G. (1982). Technological paradigms and technological trajectories. Research Policy, II(3), I47-I62. doi: http:// dx.doi.org/I0.1016/0048-7333(82)90016-6

DUYSTERS, G., de Man, A.P. (2003). Transitory alliances: an instrument for surviving turbulent industries?. R\&D Management, 33(I), 49-57. doi: http://dx.doi. org/I0.1III//467-9310.0028I

EGYEDI, T.M. (1999). Examining the relevance of paradigms to base OSI standardisation. Computer Standards \& Interfaces, 20(4), 355-374. doi: http://dx.doi.org//0.1016/ s0920-5489(98)0007।-3

FLEMING, L. (200I). Recombinant uncertainty in technological search. Management Science, 47(I), II7-I32. doi: http://dx.doi.org/I0.1287/mnsc.47.I.I I7.1067|

GAMBARDELLA, A. (1995). Science and innovation in the US Pharmaceutical Industry. Cambridge University Press, Cambridge.

GRAFF, G.D. (2003). Observing technological trajectories in patent data: empirical methods to study the emergence and growth of new technologies. American Journal of Agricultural Economics, 85(5), I266- I274. doi: http://dx.doi. org/I0.1 I I I/j.0092-5853.2003.0054I.x

GRANOVETTER, M.S. (1973). The strength of weak ties. American Journal of Sociology, 78(6), I360-1380. doi: http:// dx.doi.org// 0.1086/225469

GRILICHES, Z. (1990). Patent statistics as economic indicators: a survey. Journal of Economic Literature, 18(4), 66 I- 1707. doi: http://dx.doi.org//0.3386/w330 I

GRUPP, H. (1992). Dynamics of Science-Based Innovation, Springer, Berlin.

ISSN: 07 I8-2724. (http://www.jotmi.org) 
GUPTA, A.K., Smith, K.G., Shalley, C.E. (2006). The interplay between exploration and exploitation. Academy of Management Journal, 49(4), 693-706. doi: http://dx.doi. org//0.5465/amj.2006.22083026

HAGEDOORN, J., van Kranenburg, H., Osborn, R.N. (2003). Joint patenting amongst companies - exploring the effects of inter-firm R\&D partnering and experience. Managerial and Decision Economics, 24 (2-3), 7I-84. doi: http://dx.doi. org/ $10.1002 /$ mde. 1078

HALL, B.H., Jaffe, A., Trajtenberg, M. (2005). Market value and patent citations: a first look. NBER Working paper. Doi: http://dx.doi.org/|0.3386/w774 I

HAWKINS, R. (1999). The rise of consortia in the information and communication technology industries: emerging implications for policy. Telecommunications Policy, 23(2), 159-I73. doi: http://dx.doi.org//0.1016/s0308$596 \mid(98) 00085-8$

HE, Z.L., Wong, P.K. (2004). Exploration vs. exploitation: an empirical test of the ambidexterity hypothesis. Organization Science, 15(4), 48I-494. doi: http://dx.doi.org//0.1287/ orsc. 1040.0078

HUNG, S.W., Tang, R.H. (2008). Factors affecting the choice of technology acquisition mode: an empirical analysis of the electronic firms of Japan, Korea and Taiwan. Technovation, 28(9), 55I-563. doi: http://dx.doi.org//0.1016/j. technovation.2007.10.005

JOHNSTONE, N., Haščič, l., Poirier, J., Hemar, M., Michel, C. (20I2). Environmental policy stringency and technological innovation: evidence from survey data and patent counts. Applied Economics, 44(I7), 2157-2 170. doi: http://dx.doi.org /I0.1080/00036846.20II.560II0

JRC (2012). The 2012 EU Industrial R\&D Investment Scoreboard. Joint Research Centre, Directorate General Research and Innovation, European Commission. http://iri. jrc.ec.europa.eu/scoreboard I2.html [Accessed January 05, 2015].

KIM, C., Song, J. (2007). Creating new technology through alliances: an empirical investigation of joint patents. Technovation, 27(8),46I-470. doi:http://dx.doi.org//0.1016/j. technovation.2007.02.007

KOGUT, B. (1988). Joint ventures: theoretical and empirical perspectives. Strategic Management Journal, 9(4), 319-332. doi: http://dx.doi.org//0.1002/smj.4250090403
KOZA, M.P., Lewin, A.Y. (1998). The co-evolution of strategic alliances. Organization Science, 9(3), 255-264. doi: http:// dx.doi.org// 0.1287/orsc.9.3.255

KRACKHARDT, D. (1992). The strength of strong ties: the importance of philos in organizations. In N. Nohria \& R. Eccles (eds.), Networks and Organizations: Structure, Form and Action: 216-239. Harvard Business School Press, Boston.

LAHIRI, N. (20/0). Geographic distribution of R\&D activity: how does it affect innovation quality?. Academy of Management Journal, 53(5), I194-1209. doi: http://dx.doi. org/I0.5465/amj.20I0.54533233

LEONARD-BARTON, D. (1992). Core capabilities and core rigidities: a paradox in managing new product development. Strategic Management Journal, I3(SI), III-I25. doi: http:// dx.doi.org/I0.1002/smj.4250I3/009

LETEN, B., Belderbos, R., Van Looy, B. (2007). Technological diversification, coherence, and performance of firms. Journal of Product Innovation Management, 24(6), 567-579. doi: http://dx.doi.org/ I0. I I I I/j. I540-5885.2007.00272.x

LEVINTHAL, D.A., March,J.G. (1993).The myopia of learning. Strategic Management Journal, I4(S2), 95-II2. doi: http:// dx.doi.org//0.1002/smj.4250141009

LO STORTO, C. (2006). A method based on patent analysis for the investigation of technological innovation strategies: The European medical prostheses industry. Technovation, 26(8), 932-942. doi: http://dx.doi.org//0.1016/j. technovation.2005.10.005

MARCH, J. (199I). Exploration and exploitation in organizational learning. Organization Science, 2(I), 7I-87. doi: http://dx.doi.org//0.1287/orsc.2.I.7I

MARCH, J. (1996). Continuity and change in theories of organizational action. Organization Science, 4I(2), 278-287. doi: http://dx.doi.org// 0.2307/2393720

MARCH, J. (2006). Rationality, foolishness, and adaptive intelligence. Strategic Management Journal, 27(2), 20I-2I4. doi: http://dx.doi.org/I0.1002/smj.5I5

MAZZUCATO, M., Tancioni, M. (20I2). R\&D, patents and stock return volatility. Journal of Evolutionary Economics, 22(4), 8II-832. doi: http://dx.doi.org//0.1007/s00I9/-0I20289-x 
MICHELINO, F., Caputo, M., Cammarano, A., Lamberti, E. (20|4a). Inbound and outbound open innovation:organization and performances. Journal of Technology Management and Innovation, 9(3), 65-82. doi: http://dx.doi.org//0.4067/s07/827242014000300005

MICHELINO, F., Cammarano, A., Lamberti, E., Caputo, M. (20/4b). Measurement of open innovation through intellectual capital flows: framework and application. International Journal of Intelligent Enterprise, 2(2-3), 213235. doi: http://dx.doi.org//0.1504/ijie.2014.066679

MILLER, D.J. (2004). Firms' technological resources and the performance effects of diversification: a longitudinal study. Strategic Management Journal, 25(I I), I097-I I I9. doi: http:// dx.doi.org/I0.1002/smj.4II

MILLER, D.J., Fern, M.J., Cardinal L.B. (2007). The use of knowledge for technological innovation within diversified firms. Academy of Management Journal, 50(2), 308-326. doi: http://dx.doi.org// 0.5465/amj.2007.24634437

MINER, A.S., Bassoff, P., Moorman, C. (200I). Organizational improvisation and learning: a field study. Administrative Science Quarterly, 46(2), 304-337. doi: http://dx.doi. org/ $0.2307 / 2667089$

NAKAMURA, M., Shaver, J.M., Yeung, B. (1996). An empirical investigation of joint venture dynamics: evidence from U.S.-Japan joint ventures. International Journal of Industrial Organization, 14(4), 52I-54I. doi: http://dx.doi. org/10.1016/0167-7I87(95)00508-0

NAYYAR, P.R., Kazanjian, R.K. (1993). Organizing to attain potential benefits from information asymmetries and economies of scope in related diversified firms. Academy of Management Review, 18(4), 735-759. doi: http://dx.doi. org/I0.5465/amr.1993.9402210156

NELSON, R., Winter, S.J. (1982). An evolutionary theory of economic change. The Belknap Press of Harvard University Press, Cambridge.

NERKAR, A., Roberts, P.W. (2004). Technological and product-market experience and the success of new product introductions in the pharmaceutical industry. Strategic Management Journal, 25(89), 779-799. doi: http://dx.doi. org/l0.1002/smj.417

O'REILLY, C.A., Tushman, M.L. (2004). The ambidextrous organization. Harvard Business Review, 82, 74-82.
PAVITT, K. (1984). Sectorial patterns of technical change: towards a taxonomy and a theory. Research Policy, I3(6), 343373. doi: http://dx.doi.org/I 0.1016/0048-7333(84)900।8-0

PAVITT, K., Robson, M., Townsend, J. (1989). Technological accumulation, diversification and organization in UK companies, 1945-1983. Management Science, 35(I), 8I-99. doi: http://dx.doi.org/I0.1287/mnsc.35.I.8I

POWELL, W.W., Koput, K.W., Smith-Doerr, L. (1996). Interorganizational collaboration and the locus of innovation: networks of learning in biotechnology. Administrative Science Quarterly, 4I(I), II6-|45. doi: http://dx.doi. org/ $10.2307 / 2393988$

RAUSSER, G. (1999). Private/public research: knowledge assets and future scenarios. American Journal of Agricultural Economics, 81 (5), I 0 I I- I027. doi: http://dx.doi. org// 0.2307// 244079

SAKATA, J., Suzuki, K., Hosoya, J. (2009). The analysis of research and development efficiency in Japanese companies in the field of fuel cells using patent data. R\&D Management, 39(3), 29I-304. doi: http://dx.doi.org//0.1III/j.I467$9310.2009 .00555 . x$

SCHMIDT, S.K., Werle, R. (1998). Coordinating Technology: Studies in the international standardization of telecommunications. Oxford University Press, New York.

SCHULZ, M. (200I). The uncertain relevance of newness: organizational learning and knowledge flows. Academy of Management Journal, 44(4), 66I-68I. doi: http://dx.doi. org// 0.2307/3069409

SIMON, H.A. (1991). Bounded rationality and organizational learning. Organization Science, 2(I), I25-134. doi: http:// dx.doi.org/10.1287/orsc.2.1.125

SUZUKI, J., Kodama, F. (2004). Technology diversity of persistent innovators in Japan: two case studies of large Japanese firms. Research Policy, 33(3), 53 I-549. doi: http:// dx.doi.org/I0.1016/j.respol.2003.10.005

TEECE, D.J. (1986). Profiting from technological innovation: implications from integration, collaboration, licensing and public policy. Research Policy, 15(6), 285-305. doi: http:// dx.doi.org/10.1016/0048-7333(86)90027-2

TSANG, E.W.K. (1997). Choice of international technology transfer mode: a resource-based view. Management International Review, 37(2), I5I-168.

TUSHMAN, M.L., O'Reilly, C.A. (1996). Ambidextrous 
organizations: managing evolutionary and revolutionary change. California Management Review, 38(4), 8-30. doi: http://dx.doi.org//0.2307/41 I65852

VENAIK, S., Midgley, D. E., Devinney, T. M. (2005). Dual paths to performance: the impact of global pressures on MCN subsidiary conduct and performance. Journal of International Business Studies, 36(6), 655-675. doi: http:// dx.doi.org//0.2139/ssrn.64640I

\section{Appendix I: Example of operationalization}

In this section we illustrate how we exploited data provided by patents filed in 20II in order to perform a knowledge domain level analysis for Biotie Therapies Corp., a Finnish biotech company belonging to our sample. Table 10 shows 9 patent applications found in PATSTAT database, considering the applicant field and the CPCs recorded in each document. Ol levels are defined analysing the applicant field. No acquired or merged units were found, while some distant units (i.e. units with country code different from the Finnish one) are recorded as applicants. Only one patent is owned by units with the same country code of the parent company (i.e. "Fl"), five patents involve only distant units (i.e. Ol level 2), one patent is developed between a local and a distant unit and two patents are owned with an external partner (i.e. Lundbeck, a Danish pharma company belonging to our sample).
Starting from this information, we analyse the different 14 CPCs recorded in patent documents in order to label each one as core vs. non-core and exploitative vs. explorative. 106 patent applications are recorded from 2004 to 2010, therefore, a CPC disclosed in patents filed in $20 \mathrm{II}$ is labelled as core if it is declared in at least II patent applications from 2004 to 2010, non-core otherwise. The CPC is exploitative if we found at least one patent in the exploitation phase (i.e. from 2004 to 2006) which reports its code, explorative otherwise. For instance, the CPC "A6IK 9" is labelled as noncore explorative, since only 2 patent applications were found in the experience period and no patents were recorded in the exploitation one. The amount of inventive activities is the sum of the number of 201 I patents reporting each CPC and is equal to 20. Since Biotie is not involved in joint venturing activities, no CPCs deriving from patents developed by joint ventures have been added to our analysis and have been considered in the total amount of inventive activities. If joint ventures were found, in this step we extract only the list of CPCs deriving from their activities and the number of patents filed in $20 \mathrm{I}$, since the labelling process involves only patents from units totally owned by the company group.

\begin{tabular}{|l|l|l|l|}
\hline Application number & Applicant field & OI Level & CPCs \\
\hline FI20II 0005234 & BIOTIE THERAPIES CORPORATION [FI] & $I$ & $\begin{array}{l}\text { C07D 237; C07D 40I; C07D 403; C07D 405; C07D } \\
\text { 409; C07D 4I3 }\end{array}$ \\
\hline IL20II02I2642 & $\begin{array}{l}\text { BIOTIE THERAPIES AG OF [FI]; } \\
\text { BIOTIE THERAPIES, INC. [US] }\end{array}$ & A6IK 3I; CI2N 9 \\
\hline IL20II02I3II2 & $\begin{array}{l}\text { Biotie Therapies Corporation; } \\
\text { H.LUNDBECK A/S }\end{array}$ & 5 & C07D 489 \\
\hline WO20IIEP7I483 & BIOTIE THERAPIES GMBH [DE] & 2 & C07D 47I \\
\hline WO20IIEP72750 & BIOTIE THERAPIES GMBH [DE] & 2 & A6IK 9;A6IK 3I;A6IK 47 \\
\hline CO20II0067790 & $\begin{array}{l}\text { BIOTIE THERAPIES CORP. [FI]; } \\
\text { H. Lundbeck A/S }\end{array}$ & 5 & C07D 489 \\
\hline MX20II0004769 & BIOTIE THERAPIES, INC. [US] & 2 & A6IK 3I; CI2N 9 \\
\hline US20III 3299286 & Biotie Therapies, Inc. [US] & 2 & A6IK 3I; C07D 4I7 \\
\hline CA20II 28I6834 & BIOTIE THERAPIES, INC. [US] & 2 & A6IK 3I;A6IK 45 \\
\hline
\end{tabular}

Table 10 - Patent applications recorded in PATSTAT database with Biotie as the applicant 


\begin{tabular}{|l|l|l|l|l|l|}
\hline CPC & Experience & Exploitation & Relevance & Status & 20II Patents \\
\hline A6IK 9 & 2 & 0 & Non-core & Exploration & I \\
\hline A6IK 3I & 24 & 5 & Core & Exploitation & 5 \\
\hline A6IK 45 & 2 & 0 & Non-core & Exploration & I \\
\hline A6IK 47 & 0 & 0 & Non-core & Exploration & I \\
\hline C07D 237 & 0 & 0 & Non-core & Exploration & I \\
\hline C07D 40I & 3 & 0 & Non-core & Exploration & I \\
\hline C07D 403 & 5 & 5 & Non-core & Exploitation & I \\
\hline C07D 405 & 5 & 5 & Non-core & Exploitation & I \\
\hline C07D 409 & 8 & 5 & Non-core & Exploitation & I \\
\hline C07D 4I3 & 8 & 5 & Non-core & Exploitation & I \\
\hline C07D 4I7 & 6 & 0 & Non-core & Exploration & I \\
\hline C07D 47I & 3 & 0 & Non-core & Exploration & I \\
\hline C07D 489 & 17 & 0 & Core & Exploration & 2 \\
\hline CI2N 9 & 5 & 1 & Non-core & Exploitation & 2 \\
\hline Total amount of inventive activities & 20 & & & & \\
\hline
\end{tabular}

Table II - Labelling activity of each CPC recorded in 201 I patent applications

Since we need to examine how companies manage their R\&D efforts, we divide the number of patents filed in 20 I I into five categories (i.e. Ol levels), exploiting the information provided by PATSTAT database (Table 12).

\begin{tabular}{|c|c|c|c|c|c|c|c|}
\hline CPC & Relevance & Status & Level I & Level 2 & Level 3 & Level 4 & Level 5 \\
\hline A6IK 9 & Non-core & Exploration & 0 & I & 0 & 0 & 0 \\
\hline A6IK 31 & Core & Exploitation & 0 & 4 & 1 & 0 & 0 \\
\hline $\mathrm{A} 6 \mathrm{IK} 45$ & Non-core & Exploration & 0 & I & 0 & 0 & 0 \\
\hline A6IK 47 & Non-core & Exploration & 0 & 1 & 0 & 0 & 0 \\
\hline C07D 237 & Non-core & Exploration & I & 0 & 0 & 0 & 0 \\
\hline C07D 40I & Non-core & Exploration & I & 0 & 0 & 0 & 0 \\
\hline C07D 403 & Non-core & Exploitation & I & 0 & 0 & 0 & 0 \\
\hline C07D 405 & Non-core & Exploitation & 1 & 0 & 0 & 0 & 0 \\
\hline C07D 409 & Non-core & Exploitation & I & 0 & 0 & 0 & 0 \\
\hline C07D 4I3 & Non-core & Exploitation & I & 0 & 0 & 0 & 0 \\
\hline C07D 417 & Non-core & Exploration & 0 & I & 0 & 0 & 0 \\
\hline C07D 47I & Non-core & Exploration & 0 & 1 & 0 & 0 & 0 \\
\hline C07D 489 & Core & Exploration & 0 & 0 & 0 & 0 & 2 \\
\hline $\mathrm{CI} 2 \mathrm{~N} 9$ & Non-core & Exploitation & 0 & I & I & 0 & 0 \\
\hline Total amount of inventive activities & 6 & 10 & 2 & 0 & 2 & & \\
\hline Share of Ol activities & $30.00 \%$ & $50.00 \%$ & $10.00 \%$ & $0.00 \%$ & $10.00 \%$ & & \\
\hline
\end{tabular}

Table 12 - Shares of the five levels of Ol adoption

ISSN: 07 I8-2724. (http://www.jotmi.org) 
Table 13 and 14 summarise the results found in the analysis of the knowledge domains: only $35 \%$ of inventive activities are pursued within relevant technological fields, while exploitative processes prevail on explorative ones. In detail, the non-core exploration strategy is the prevailing one, with 7 inventive activities involving less relevant knowledge domains in which the firms lacks of consolidated experience.

\begin{tabular}{|l|l|l|}
\hline Label & Number of occurrences & Share \\
\hline Core & 7 & $35.00 \%$ \\
\hline Non-core & 13 & $65.00 \%$ \\
\hline Exploitation & 11 & $55.00 \%$ \\
\hline Exploration & 9 & $45.00 \%$ \\
\hline
\end{tabular}

Table 13 - Relevance and exploitation vs. exploration shares of Biotie's inventive activities

\begin{tabular}{|l|l|l|}
\hline Label & Number of occurrences & Share \\
\hline Core exploitation & 5 & $25.00 \%$ \\
\hline Core exploration & 2 & $10.00 \%$ \\
\hline Non-core exploitation & 6 & $30.00 \%$ \\
\hline Non-core exploration & 7 & $35.00 \%$ \\
\hline Total & 20 & $100.00 \%$ \\
\hline
\end{tabular}

Table 14 - Shares of knowledge domain labels
In order to study how companies manage and organize their inventive activities, we cumulated R\&D efforts grouping them by the knowledge domain labels. Table 15 represents the effective output of our framework, which we may exploit in order to perform benchmark with competitors or by cumulating results deriving from all the companies belonging to our sample in order to execute an industry-level analysis.

Tables 16 and 17 show the results found analysing Biotie's innovative activities: levels from I to 3 cover the totality of non-core activities and core exploitative ones, while core explorative strategies are fully pursued with the external partner.

\begin{tabular}{|l|l|l|l|l|l|l|}
\hline Label & Level I & Level 2 & Level 3 & Level 4 & Level 5 & Total \\
\hline Core exploitation & $0.00 \%$ & $80.00 \%$ & $20.00 \%$ & $0.00 \%$ & $0.00 \%$ & $100.00 \%$ \\
\hline Core exploration & $0.00 \%$ & $0.00 \%$ & $0.00 \%$ & $0.00 \%$ & $100.00 \%$ & $100.00 \%$ \\
\hline Non-core exploitation & $66.67 \%$ & $16.67 \%$ & $16.67 \%$ & $0.00 \%$ & $0.00 \%$ & $100.00 \%$ \\
\hline Non-core exploration & $28.57 \%$ & $71.43 \%$ & $0.00 \%$ & $0.00 \%$ & $0.00 \%$ & $100.00 \%$ \\
\hline
\end{tabular}

Table 16 - Share of Ol activities for each innovation strategy

\begin{tabular}{|l|l|l|l|l|l|}
\hline Label & Level I & Level 2 & Level 3 & Level 4 & Level 5 \\
\hline Core exploitation & $0.00 \%$ & $40.00 \%$ & $50.00 \%$ & - & $0.00 \%$ \\
\hline Core exploration & $0.00 \%$ & $0.00 \%$ & $0.00 \%$ & - & $100.00 \%$ \\
\hline Non-core exploitation & $66.67 \%$ & $10.00 \%$ & $50.00 \%$ & - & $0.00 \%$ \\
\hline Non-core exploration & $33.33 \%$ & $50.00 \%$ & $0.00 \%$ & - & $0.00 \%$ \\
\hline Total & $100.00 \%$ & $100.00 \%$ & $100.00 \%$ & - & $100.00 \%$ \\
\hline
\end{tabular}

Table 17 - Share of innovation strategies at each OI level

ISSN: 07 I8-2724. (http://www.jotmi.org)

Journal of Technology Management \& Innovation (c) Universidad Alberto Hurtado, Facultad de Economía y Negocios. 


\section{Appendix 2: List of companies and their joint ventures}

A) List of companies with the shares of innovation strategies and OI levels

\begin{tabular}{|c|c|c|c|c|c|c|c|c|}
\hline Company & Industry & Core & Exploitation & Level I & Level 2 & Level 3 & Level 4 & Level 5 \\
\hline $4 \mathrm{SC}$ & $\mathrm{BP}$ & $17 \%$ & $77 \%$ & $100 \%$ & $0 \%$ & $0 \%$ & $0 \%$ & $0 \%$ \\
\hline Actelion & BP & $38 \%$ & $80 \%$ & $91 \%$ & $0 \%$ & $0 \%$ & $0 \%$ & $9 \%$ \\
\hline Active & $\mathrm{BP}$ & $100 \%$ & $100 \%$ & $100 \%$ & $0 \%$ & $0 \%$ & $0 \%$ & $0 \%$ \\
\hline Affymetrix & $\mathrm{BP}$ & $57 \%$ & $86 \%$ & $96 \%$ & $2 \%$ & $0 \%$ & $0 \%$ & $2 \%$ \\
\hline Agennix & $\mathrm{BP}$ & $56 \%$ & $56 \%$ & $44 \%$ & $56 \%$ & $0 \%$ & $0 \%$ & $0 \%$ \\
\hline Alexion & $\mathrm{BP}$ & $72 \%$ & $88 \%$ & $89 \%$ & $11 \%$ & $0 \%$ & $0 \%$ & $0 \%$ \\
\hline ALK & $\mathrm{BP}$ & $64 \%$ & $80 \%$ & $80 \%$ & $20 \%$ & $0 \%$ & $0 \%$ & $0 \%$ \\
\hline Allergan & $\mathrm{BP}$ & $29 \%$ & $81 \%$ & $93 \%$ & $4 \%$ & $0 \%$ & $0 \%$ & $3 \%$ \\
\hline Almirall & $\mathrm{BP}$ & $43 \%$ & $79 \%$ & $91 \%$ & $3 \%$ & $2 \%$ & $0 \%$ & $4 \%$ \\
\hline Amgen & $\mathrm{BP}$ & $64 \%$ & $94 \%$ & $90 \%$ & $3 \%$ & $0 \%$ & $0 \%$ & $8 \%$ \\
\hline Arena & $\mathrm{BP}$ & $60 \%$ & $98 \%$ & $100 \%$ & $0 \%$ & $0 \%$ & $0 \%$ & $0 \%$ \\
\hline Ark & $\mathrm{BP}$ & $40 \%$ & $60 \%$ & $100 \%$ & $0 \%$ & $0 \%$ & $0 \%$ & $0 \%$ \\
\hline AstraZeneca & $\mathrm{BP}$ & $26 \%$ & $91 \%$ & $4 \%$ & $76 \%$ & $1 \%$ & $0 \%$ & $19 \%$ \\
\hline Bavarian & $\mathrm{BP}$ & $81 \%$ & $92 \%$ & $97 \%$ & $0 \%$ & $0 \%$ & $0 \%$ & $3 \%$ \\
\hline Biogen & $\mathrm{BP}$ & $71 \%$ & $99 \%$ & $85 \%$ & $1 \%$ & $0 \%$ & $0 \%$ & $14 \%$ \\
\hline Bioinvent & $\mathrm{BP}$ & $92 \%$ & $96 \%$ & $100 \%$ & $0 \%$ & $0 \%$ & $0 \%$ & $0 \%$ \\
\hline Biomarin & $\mathrm{BP}$ & $28 \%$ & $37 \%$ & $100 \%$ & $0 \%$ & $0 \%$ & $0 \%$ & $0 \%$ \\
\hline Biotest & $\mathrm{BP}$ & $68 \%$ & $68 \%$ & $92 \%$ & $0 \%$ & $0 \%$ & $0 \%$ & $8 \%$ \\
\hline Biotie & $\mathrm{BP}$ & $35 \%$ & $55 \%$ & $30 \%$ & $50 \%$ & $10 \%$ & $0 \%$ & $10 \%$ \\
\hline Bioton & $\mathrm{BP}$ & $23 \%$ & $0 \%$ & $0 \%$ & $100 \%$ & $0 \%$ & $0 \%$ & $0 \%$ \\
\hline Boehringer & $\mathrm{BP}$ & $18 \%$ & $97 \%$ & $94 \%$ & $0 \%$ & $0 \%$ & $0 \%$ & $5 \%$ \\
\hline BTG & $\mathrm{BP}$ & $20 \%$ & $78 \%$ & $76 \%$ & $24 \%$ & $0 \%$ & $0 \%$ & $0 \%$ \\
\hline Celgene & $\mathrm{BP}$ & $41 \%$ & $82 \%$ & $66 \%$ & $34 \%$ & $0 \%$ & $0 \%$ & $0 \%$ \\
\hline $\mathrm{CHR}$ & $\mathrm{BP}$ & $65 \%$ & $90 \%$ & $96 \%$ & $0 \%$ & $0 \%$ & $0 \%$ & $4 \%$ \\
\hline Cosmo & $\mathrm{BP}$ & $59 \%$ & $59 \%$ & $4 \%$ & $96 \%$ & $0 \%$ & $0 \%$ & $0 \%$ \\
\hline CSL & $\mathrm{BP}$ & $53 \%$ & $78 \%$ & $61 \%$ & $27 \%$ & $0 \%$ & $0 \%$ & $12 \%$ \\
\hline Cubist & $\mathrm{BP}$ & $23 \%$ & $27 \%$ & $13 \%$ & $77 \%$ & $0 \%$ & $0 \%$ & $10 \%$ \\
\hline Dendreon & $\mathrm{BP}$ & $100 \%$ & $100 \%$ & $25 \%$ & $0 \%$ & $0 \%$ & $0 \%$ & $75 \%$ \\
\hline DiaSorin & $\mathrm{BP}$ & $33 \%$ & $33 \%$ & $100 \%$ & $0 \%$ & $0 \%$ & $0 \%$ & $0 \%$ \\
\hline Egis & $\mathrm{BP}$ & $39 \%$ & $52 \%$ & $86 \%$ & $0 \%$ & $0 \%$ & $0 \%$ & $14 \%$ \\
\hline Elan & $\mathrm{BP}$ & $40 \%$ & $96 \%$ & $27 \%$ & $49 \%$ & $1 \%$ & $0 \%$ & $24 \%$ \\
\hline EliLilly & $\mathrm{BP}$ & $36 \%$ & $96 \%$ & $69 \%$ & $19 \%$ & $0 \%$ & $0 \%$ & $13 \%$ \\
\hline Endo & $\mathrm{BP}$ & $79 \%$ & $89 \%$ & $100 \%$ & $0 \%$ & $0 \%$ & $0 \%$ & $0 \%$ \\
\hline Epigenomics & $\mathrm{BP}$ & $89 \%$ & $100 \%$ & $100 \%$ & $0 \%$ & $0 \%$ & $0 \%$ & $0 \%$ \\
\hline Evotec & $\mathrm{BP}$ & $29 \%$ & $29 \%$ & $71 \%$ & $29 \%$ & $0 \%$ & $0 \%$ & $0 \%$ \\
\hline Exelixis & $\mathrm{BP}$ & $56 \%$ & $84 \%$ & $85 \%$ & $0 \%$ & $0 \%$ & $0 \%$ & $15 \%$ \\
\hline Galapagos & $\mathrm{BP}$ & $67 \%$ & $83 \%$ & $75 \%$ & $23 \%$ & $0 \%$ & $0 \%$ & $2 \%$ \\
\hline GedeonRichter & $\mathrm{BP}$ & $38 \%$ & $79 \%$ & $87 \%$ & $8 \%$ & $0 \%$ & $0 \%$ & $5 \%$ \\
\hline Genmab & $\mathrm{BP}$ & $92 \%$ & $96 \%$ & $100 \%$ & $0 \%$ & $0 \%$ & $0 \%$ & $0 \%$ \\
\hline
\end{tabular}

ISSN: 07 I8-2724. (http://www.jotmi.org)

Journal of Technology Management \& Innovation (c) Universidad Alberto Hurtado, Facultad de Economía y Negocios. 


\begin{tabular}{|c|c|c|c|c|c|c|c|c|}
\hline Gilead & BP & $41 \%$ & $78 \%$ & $91 \%$ & $0 \%$ & $0 \%$ & $0 \%$ & $8 \%$ \\
\hline GSK & BP & $27 \%$ & $96 \%$ & $40 \%$ & $51 \%$ & $2 \%$ & $1 \%$ & $5 \%$ \\
\hline Guerbet & $\mathrm{BP}$ & $47 \%$ & $59 \%$ & $100 \%$ & $0 \%$ & $0 \%$ & $0 \%$ & $0 \%$ \\
\hline GW & $\mathrm{BP}$ & $99 \%$ & $77 \%$ & $19 \%$ & $0 \%$ & $0 \%$ & $0 \%$ & $81 \%$ \\
\hline Hospira & BP & $46 \%$ & $52 \%$ & $72 \%$ & $28 \%$ & $0 \%$ & $0 \%$ & $0 \%$ \\
\hline Illumina & BP & $31 \%$ & $87 \%$ & $82 \%$ & $16 \%$ & $0 \%$ & $0 \%$ & $3 \%$ \\
\hline Incyte & BP & $61 \%$ & $83 \%$ & $95 \%$ & $0 \%$ & $2 \%$ & $0 \%$ & $3 \%$ \\
\hline Innate & BP & $60 \%$ & $97 \%$ & $20 \%$ & $0 \%$ & $0 \%$ & $0 \%$ & $80 \%$ \\
\hline Intercell & $\mathrm{BP}$ & $72 \%$ & $94 \%$ & $94 \%$ & $0 \%$ & $6 \%$ & $0 \%$ & $0 \%$ \\
\hline Isis & $\mathrm{BP}$ & $80 \%$ & $98 \%$ & $75 \%$ & $0 \%$ & $0 \%$ & $0 \%$ & $25 \%$ \\
\hline $\mathrm{J \& J}$ & $\mathrm{BP}$ & $18 \%$ & $97 \%$ & $70 \%$ & $26 \%$ & $0 \%$ & $0 \%$ & $4 \%$ \\
\hline Krka & $\mathrm{BP}$ & $70 \%$ & $85 \%$ & $95 \%$ & $0 \%$ & $0 \%$ & $0 \%$ & $5 \%$ \\
\hline Laboratorios Rovi & $\mathrm{BP}$ & $79 \%$ & $82 \%$ & $94 \%$ & $6 \%$ & $0 \%$ & $0 \%$ & $0 \%$ \\
\hline Lexicon & $\mathrm{BP}$ & $36 \%$ & $75 \%$ & $100 \%$ & $0 \%$ & $0 \%$ & $0 \%$ & $0 \%$ \\
\hline Lundbeck & $\mathrm{BP}$ & $34 \%$ & $82 \%$ & $96 \%$ & $2 \%$ & $0 \%$ & $0 \%$ & $3 \%$ \\
\hline Meda & $\mathrm{BP}$ & $57 \%$ & $68 \%$ & $25 \%$ & $61 \%$ & $0 \%$ & $0 \%$ & $14 \%$ \\
\hline Medicines & $\mathrm{BP}$ & $59 \%$ & $59 \%$ & $33 \%$ & $67 \%$ & $0 \%$ & $0 \%$ & $0 \%$ \\
\hline MediGene & $\mathrm{BP}$ & $64 \%$ & $100 \%$ & $64 \%$ & $0 \%$ & $0 \%$ & $0 \%$ & $36 \%$ \\
\hline Medivir & $\mathrm{BP}$ & $64 \%$ & $86 \%$ & $24 \%$ & $42 \%$ & $0 \%$ & $0 \%$ & $34 \%$ \\
\hline MerckDE & $\mathrm{BP}$ & $13 \%$ & $88 \%$ & $71 \%$ & $23 \%$ & $0 \%$ & $0 \%$ & $6 \%$ \\
\hline MerckUS & $\mathrm{BP}$ & $31 \%$ & $96 \%$ & $4 \%$ & $83 \%$ & $0 \%$ & $5 \%$ & $8 \%$ \\
\hline Merz & $\mathrm{BP}$ & $43 \%$ & $75 \%$ & $89 \%$ & $2 \%$ & $0 \%$ & $0 \%$ & $10 \%$ \\
\hline Morphosys & $\mathrm{BP}$ & $62 \%$ & $76 \%$ & $96 \%$ & $0 \%$ & $0 \%$ & $0 \%$ & $4 \%$ \\
\hline Mylan & $\mathrm{BP}$ & $21 \%$ & $49 \%$ & $43 \%$ & $43 \%$ & $0 \%$ & $15 \%$ & $0 \%$ \\
\hline Nektar & $\mathrm{BP}$ & $43 \%$ & $82 \%$ & $94 \%$ & $0 \%$ & $0 \%$ & $0 \%$ & $6 \%$ \\
\hline NeuroSearch & $\mathrm{BP}$ & $38 \%$ & $92 \%$ & $100 \%$ & $0 \%$ & $0 \%$ & $0 \%$ & $0 \%$ \\
\hline Newron & $\mathrm{BP}$ & $72 \%$ & $72 \%$ & $100 \%$ & $0 \%$ & $0 \%$ & $0 \%$ & $0 \%$ \\
\hline $\mathrm{NicOx}$ & $\mathrm{BP}$ & $31 \%$ & $91 \%$ & $88 \%$ & $0 \%$ & $0 \%$ & $0 \%$ & $13 \%$ \\
\hline Novartis & $\mathrm{BP}$ & $14 \%$ & $93 \%$ & $66 \%$ & $24 \%$ & $0 \%$ & $0 \%$ & $10 \%$ \\
\hline NovoNordisk & $\mathrm{BP}$ & $55 \%$ & $96 \%$ & $78 \%$ & $17 \%$ & $0 \%$ & $0 \%$ & $5 \%$ \\
\hline NPS & $\mathrm{BP}$ & $0 \%$ & $100 \%$ & $100 \%$ & $0 \%$ & $0 \%$ & $0 \%$ & $0 \%$ \\
\hline Onyx & $\mathrm{BP}$ & $54 \%$ & $38 \%$ & $95 \%$ & $0 \%$ & $0 \%$ & $0 \%$ & $5 \%$ \\
\hline Orexo & $\mathrm{BP}$ & $63 \%$ & $54 \%$ & $89 \%$ & $9 \%$ & $0 \%$ & $0 \%$ & $3 \%$ \\
\hline Oxford & $\mathrm{BP}$ & $74 \%$ & $79 \%$ & $100 \%$ & $0 \%$ & $0 \%$ & $0 \%$ & $0 \%$ \\
\hline Paion & $\mathrm{BP}$ & $25 \%$ & $25 \%$ & $0 \%$ & $50 \%$ & $0 \%$ & $0 \%$ & $50 \%$ \\
\hline Pfizer & $\mathrm{BP}$ & $18 \%$ & $95 \%$ & $35 \%$ & $46 \%$ & $4 \%$ & $1 \%$ & $15 \%$ \\
\hline Pharming & $\mathrm{BP}$ & $90 \%$ & $95 \%$ & $100 \%$ & $0 \%$ & $0 \%$ & $0 \%$ & $0 \%$ \\
\hline Qiagen & $\mathrm{BP}$ & $56 \%$ & $87 \%$ & $1 \%$ & $99 \%$ & $0 \%$ & $0 \%$ & $0 \%$ \\
\hline Recordati & $\mathrm{BP}$ & $25 \%$ & $25 \%$ & $0 \%$ & $100 \%$ & $0 \%$ & $0 \%$ & $0 \%$ \\
\hline Regeneron & $\mathrm{BP}$ & $62 \%$ & $97 \%$ & $98 \%$ & $0 \%$ & $0 \%$ & $0 \%$ & $2 \%$ \\
\hline Roche & $\mathrm{BP}$ & $15 \%$ & $97 \%$ & $53 \%$ & $30 \%$ & $9 \%$ & $0 \%$ & $8 \%$ \\
\hline Salix & $\mathrm{BP}$ & $61 \%$ & $64 \%$ & $94 \%$ & $0 \%$ & $0 \%$ & $0 \%$ & $6 \%$ \\
\hline Sanofi & $\mathrm{BP}$ & $12 \%$ & $92 \%$ & $14 \%$ & $80 \%$ & $0 \%$ & $0 \%$ & $6 \%$ \\
\hline Shire & $\mathrm{BP}$ & $39 \%$ & $71 \%$ & $0 \%$ & $98 \%$ & $0 \%$ & $0 \%$ & $2 \%$ \\
\hline Silence & $\mathrm{BP}$ & $90 \%$ & $80 \%$ & $0 \%$ & $40 \%$ & $0 \%$ & $0 \%$ & $60 \%$ \\
\hline
\end{tabular}

ISSN: 07 I8-2724. (http://www.jotmi.org) 


\begin{tabular}{|c|c|c|c|c|c|c|c|c|}
\hline SOB & $\mathrm{BP}$ & $33 \%$ & $75 \%$ & $58 \%$ & $0 \%$ & $0 \%$ & $0 \%$ & $42 \%$ \\
\hline Stada & $\mathrm{BP}$ & $33 \%$ & $33 \%$ & $30 \%$ & $70 \%$ & $0 \%$ & $0 \%$ & $0 \%$ \\
\hline Sygnis & $\mathrm{BP}$ & $35 \%$ & $65 \%$ & $74 \%$ & $0 \%$ & $0 \%$ & $0 \%$ & $26 \%$ \\
\hline Symphogen & BP & $82 \%$ & $81 \%$ & $45 \%$ & $0 \%$ & $0 \%$ & $0 \%$ & $55 \%$ \\
\hline Teva & BP & $38 \%$ & $86 \%$ & $19 \%$ & $51 \%$ & $4 \%$ & $15 \%$ & $10 \%$ \\
\hline Theravance & $\mathrm{BP}$ & $24 \%$ & $82 \%$ & $100 \%$ & $0 \%$ & $0 \%$ & $0 \%$ & $0 \%$ \\
\hline ThromboGenics & $\mathrm{BP}$ & $100 \%$ & $71 \%$ & $57 \%$ & $0 \%$ & $0 \%$ & $0 \%$ & $43 \%$ \\
\hline TiGenix & $\mathrm{BP}$ & $70 \%$ & $10 \%$ & $25 \%$ & $40 \%$ & $0 \%$ & $0 \%$ & $35 \%$ \\
\hline TopoTarget & $\mathrm{BP}$ & $23 \%$ & $61 \%$ & $42 \%$ & $58 \%$ & $0 \%$ & $0 \%$ & $0 \%$ \\
\hline Transgene & $\mathrm{BP}$ & $51 \%$ & $47 \%$ & $95 \%$ & $0 \%$ & $0 \%$ & $0 \%$ & $5 \%$ \\
\hline UCB & $\mathrm{BP}$ & $37 \%$ & $91 \%$ & $67 \%$ & $31 \%$ & $0 \%$ & $0 \%$ & $3 \%$ \\
\hline United & BP & $30 \%$ & $47 \%$ & $63 \%$ & $35 \%$ & $0 \%$ & $0 \%$ & $2 \%$ \\
\hline Vectura & $\mathrm{BP}$ & $92 \%$ & $94 \%$ & $100 \%$ & $0 \%$ & $0 \%$ & $0 \%$ & $0 \%$ \\
\hline Vernalis & $\mathrm{BP}$ & $33 \%$ & $100 \%$ & $0 \%$ & $0 \%$ & $0 \%$ & $0 \%$ & $100 \%$ \\
\hline Vertex & $\mathrm{BP}$ & $53 \%$ & $99 \%$ & $96 \%$ & $1 \%$ & $0 \%$ & $0 \%$ & $2 \%$ \\
\hline Vetoquinol & $\mathrm{BP}$ & $100 \%$ & $0 \%$ & $100 \%$ & $0 \%$ & $0 \%$ & $0 \%$ & $0 \%$ \\
\hline WarnerChilcott & $\mathrm{BP}$ & $60 \%$ & $100 \%$ & $10 \%$ & $90 \%$ & $0 \%$ & $0 \%$ & $0 \%$ \\
\hline Wilex & $\mathrm{BP}$ & $80 \%$ & $100 \%$ & $60 \%$ & $40 \%$ & $0 \%$ & $0 \%$ & $0 \%$ \\
\hline Zeltia & $\mathrm{BP}$ & $34 \%$ & $68 \%$ & $97 \%$ & $0 \%$ & $0 \%$ & $0 \%$ & $3 \%$ \\
\hline Adtran & THE & $30 \%$ & $70 \%$ & $100 \%$ & $0 \%$ & $0 \%$ & $0 \%$ & $0 \%$ \\
\hline ADVA Optical Networking & THE & $50 \%$ & $10 \%$ & $100 \%$ & $0 \%$ & $0 \%$ & $0 \%$ & $0 \%$ \\
\hline Advanced Digital Broadcast & $\overline{T \text { THE }}$ & $25 \%$ & $8 \%$ & $100 \%$ & $0 \%$ & $0 \%$ & $0 \%$ & $0 \%$ \\
\hline Advanced Micro Devices & $\overline{T H E}$ & $47 \%$ & $94 \%$ & $28 \%$ & $0 \%$ & $0 \%$ & $0 \%$ & $72 \%$ \\
\hline Advanced Semiconductor Engineering & THE & $91 \%$ & $95 \%$ & $71 \%$ & $0 \%$ & $0 \%$ & $5 \%$ & $24 \%$ \\
\hline Advantest & THE & $30 \%$ & $84 \%$ & $84 \%$ & $3 \%$ & $1 \%$ & $0 \%$ & $11 \%$ \\
\hline Aixtron & THE & $76 \%$ & $89 \%$ & $99 \%$ & $1 \%$ & $0 \%$ & $0 \%$ & $0 \%$ \\
\hline Alcatel-Lucent & THE & $10 \%$ & $94 \%$ & $39 \%$ & $54 \%$ & $2 \%$ & $1 \%$ & $5 \%$ \\
\hline Altera & THE & $19 \%$ & $88 \%$ & $100 \%$ & $0 \%$ & $0 \%$ & $0 \%$ & $0 \%$ \\
\hline Analog Devices & THE & $6 \%$ & $76 \%$ & $100 \%$ & $0 \%$ & $0 \%$ & $0 \%$ & $0 \%$ \\
\hline Anoto & THE & $100 \%$ & $100 \%$ & $100 \%$ & $0 \%$ & $0 \%$ & $0 \%$ & $0 \%$ \\
\hline Apple & THE & $15 \%$ & $91 \%$ & $100 \%$ & $0 \%$ & $0 \%$ & $0 \%$ & $0 \%$ \\
\hline Applied Materials & THE & $54 \%$ & $90 \%$ & $92 \%$ & $6 \%$ & $0 \%$ & $0 \%$ & $2 \%$ \\
\hline ARM & THE & $38 \%$ & $83 \%$ & $98 \%$ & $2 \%$ & $0 \%$ & $0 \%$ & $0 \%$ \\
\hline Arris & THE & $15 \%$ & $88 \%$ & $14 \%$ & $83 \%$ & $0 \%$ & $0 \%$ & $3 \%$ \\
\hline Aruba Networks & THE & $44 \%$ & $59 \%$ & $85 \%$ & $15 \%$ & $0 \%$ & $0 \%$ & $0 \%$ \\
\hline ASM International & THE & $31 \%$ & $83 \%$ & $23 \%$ & $77 \%$ & $0 \%$ & $0 \%$ & $0 \%$ \\
\hline ASML Holding & THE & $59 \%$ & $92 \%$ & $91 \%$ & $0 \%$ & $1 \%$ & $0 \%$ & $8 \%$ \\
\hline Atmel & THE & $19 \%$ & $80 \%$ & $89 \%$ & $11 \%$ & $0 \%$ & $0 \%$ & $1 \%$ \\
\hline Austriamicrosystems & THE & $4 \%$ & $78 \%$ & $99 \%$ & $0 \%$ & $0 \%$ & $0 \%$ & $1 \%$ \\
\hline Avago Technologies & THE & $28 \%$ & $83 \%$ & $99 \%$ & $1 \%$ & $0 \%$ & $0 \%$ & $0 \%$ \\
\hline Avaya & THE & $46 \%$ & $94 \%$ & $100 \%$ & $0 \%$ & $0 \%$ & $0 \%$ & $0 \%$ \\
\hline Axis & THE & $37 \%$ & $55 \%$ & $99 \%$ & $1 \%$ & $0 \%$ & $0 \%$ & $0 \%$ \\
\hline Broadcom & THE & $5 \%$ & $94 \%$ & $100 \%$ & $0 \%$ & $0 \%$ & $0 \%$ & $0 \%$ \\
\hline Brocade Communications Systems & THE & $74 \%$ & $86 \%$ & $86 \%$ & $12 \%$ & $1 \%$ & $0 \%$ & $1 \%$ \\
\hline Bull & $\overline{T H E}$ & $21 \%$ & $52 \%$ & $92 \%$ & $4 \%$ & $0 \%$ & $0 \%$ & $5 \%$ \\
\hline
\end{tabular}

ISSN: 07 I8-2724. (http://www.jotmi.org) 


\begin{tabular}{|c|c|c|c|c|c|c|c|c|}
\hline Calix & THE & $30 \%$ & $44 \%$ & $59 \%$ & $41 \%$ & $0 \%$ & $0 \%$ & $0 \%$ \\
\hline Canon & THE & $17 \%$ & $95 \%$ & $96 \%$ & $2 \%$ & $0 \%$ & $0 \%$ & $2 \%$ \\
\hline Cavium Networks & THE & $22 \%$ & $22 \%$ & $100 \%$ & $0 \%$ & $0 \%$ & $0 \%$ & $0 \%$ \\
\hline Ciena & THE & $52 \%$ & $88 \%$ & $60 \%$ & $40 \%$ & $0 \%$ & $0 \%$ & $0 \%$ \\
\hline Corning & THE & $7 \%$ & $64 \%$ & $62 \%$ & $0 \%$ & $0 \%$ & $0 \%$ & $38 \%$ \\
\hline Cree & THE & $49 \%$ & $96 \%$ & $98 \%$ & $2 \%$ & $0 \%$ & $0 \%$ & $0 \%$ \\
\hline CSR UK & THE & $16 \%$ & $45 \%$ & $53 \%$ & $47 \%$ & $0 \%$ & $0 \%$ & $0 \%$ \\
\hline Cypress Semiconductor & THE & $26 \%$ & $76 \%$ & $97 \%$ & $3 \%$ & $0 \%$ & $0 \%$ & $0 \%$ \\
\hline Dell & THE & $18 \%$ & $92 \%$ & $88 \%$ & $10 \%$ & $0 \%$ & $0 \%$ & $2 \%$ \\
\hline Delta Electronics & THE & $2 \%$ & $68 \%$ & $8 \%$ & $86 \%$ & $1 \%$ & $2 \%$ & $3 \%$ \\
\hline Dialog Semiconductor & THE & $13 \%$ & $23 \%$ & $0 \%$ & $100 \%$ & $0 \%$ & $0 \%$ & $0 \%$ \\
\hline Electronics for imaging & THE & $31 \%$ & $28 \%$ & $100 \%$ & $0 \%$ & $0 \%$ & $0 \%$ & $0 \%$ \\
\hline ELMOS Semiconductor & THE & $7 \%$ & $10 \%$ & $96 \%$ & $1 \%$ & $3 \%$ & $0 \%$ & $0 \%$ \\
\hline Emulex & THE & $33 \%$ & $89 \%$ & $100 \%$ & $0 \%$ & $0 \%$ & $0 \%$ & $0 \%$ \\
\hline Ericsson & THE & $6 \%$ & $93 \%$ & $73 \%$ & $3 \%$ & $0 \%$ & $0 \%$ & $24 \%$ \\
\hline F5 Networks & THE & $69 \%$ & $82 \%$ & $100 \%$ & $0 \%$ & $0 \%$ & $0 \%$ & $0 \%$ \\
\hline Fairchild Semiconductor & THE & $49 \%$ & $86 \%$ & $57 \%$ & $38 \%$ & $5 \%$ & $0 \%$ & $0 \%$ \\
\hline FEI & THE & $70 \%$ & $82 \%$ & $100 \%$ & $0 \%$ & $0 \%$ & $0 \%$ & $0 \%$ \\
\hline Filtronic & THE & $38 \%$ & $0 \%$ & $100 \%$ & $0 \%$ & $0 \%$ & $0 \%$ & $0 \%$ \\
\hline Finisar & THE & $68 \%$ & $92 \%$ & $100 \%$ & $0 \%$ & $0 \%$ & $0 \%$ & $0 \%$ \\
\hline GN Store Nord & THE & $56 \%$ & $65 \%$ & $100 \%$ & $0 \%$ & $0 \%$ & $0 \%$ & $0 \%$ \\
\hline Harmonic & THE & $62 \%$ & $69 \%$ & $100 \%$ & $0 \%$ & $0 \%$ & $0 \%$ & $0 \%$ \\
\hline Harris & THE & $0 \%$ & $53 \%$ & $95 \%$ & $0 \%$ & $0 \%$ & $0 \%$ & $5 \%$ \\
\hline Hewlett-Packard & THE & $8 \%$ & $91 \%$ & $96 \%$ & $3 \%$ & $0 \%$ & $0 \%$ & $1 \%$ \\
\hline HTC & THE & $10 \%$ & $79 \%$ & $100 \%$ & $0 \%$ & $0 \%$ & $0 \%$ & $0 \%$ \\
\hline Huawei Technologies & THE & $12 \%$ & $96 \%$ & $98 \%$ & $0 \%$ & $0 \%$ & $0 \%$ & $2 \%$ \\
\hline Hynix Semiconductor & $\overline{T \text { THE }}$ & $36 \%$ & $97 \%$ & $99 \%$ & $0 \%$ & $0 \%$ & $0 \%$ & $1 \%$ \\
\hline Imagination Technologies & THE & $41 \%$ & $49 \%$ & $87 \%$ & $13 \%$ & $0 \%$ & $0 \%$ & $0 \%$ \\
\hline Infineon Technologies & THE & $44 \%$ & $94 \%$ & $84 \%$ & $14 \%$ & $0 \%$ & $0 \%$ & $2 \%$ \\
\hline Integrated Device Technology & THE & $6 \%$ & $33 \%$ & $89 \%$ & $11 \%$ & $0 \%$ & $0 \%$ & $0 \%$ \\
\hline Intel & THE & $8 \%$ & $92 \%$ & $94 \%$ & $5 \%$ & $0 \%$ & $0 \%$ & $1 \%$ \\
\hline Intermec & THE & $8 \%$ & $31 \%$ & $28 \%$ & $72 \%$ & $0 \%$ & $0 \%$ & $0 \%$ \\
\hline International Rectifier & THE & $43 \%$ & $94 \%$ & $100 \%$ & $0 \%$ & $0 \%$ & $0 \%$ & $0 \%$ \\
\hline Intersil & THE & $23 \%$ & $69 \%$ & $99 \%$ & $1 \%$ & $0 \%$ & $0 \%$ & $0 \%$ \\
\hline JDS Uniphase & THE & $9 \%$ & $76 \%$ & $93 \%$ & $3 \%$ & $0 \%$ & $0 \%$ & $5 \%$ \\
\hline Juniper Networks & THE & $57 \%$ & $80 \%$ & $100 \%$ & $0 \%$ & $0 \%$ & $0 \%$ & $0 \%$ \\
\hline Kla-Tencor & THE & $46 \%$ & $89 \%$ & $96 \%$ & $2 \%$ & $0 \%$ & $0 \%$ & $2 \%$ \\
\hline Kontron & THE & $0 \%$ & $0 \%$ & $0 \%$ & $100 \%$ & $0 \%$ & $0 \%$ & $0 \%$ \\
\hline Kulicke \& Soffa & THE & $74 \%$ & $78 \%$ & $94 \%$ & $6 \%$ & $0 \%$ & $0 \%$ & $0 \%$ \\
\hline Lam Research & THE & $51 \%$ & $84 \%$ & $73 \%$ & $26 \%$ & $2 \%$ & $0 \%$ & $0 \%$ \\
\hline Lattice Semiconductor & THE & $50 \%$ & $50 \%$ & $100 \%$ & $0 \%$ & $0 \%$ & $0 \%$ & $0 \%$ \\
\hline Lenovo & THE & $34 \%$ & $84 \%$ & $0 \%$ & $84 \%$ & $0 \%$ & $16 \%$ & $0 \%$ \\
\hline Lexmark & THE & $23 \%$ & $51 \%$ & $100 \%$ & $0 \%$ & $0 \%$ & $0 \%$ & $0 \%$ \\
\hline Linear Technology & THE & $26 \%$ & $59 \%$ & $90 \%$ & $10 \%$ & $0 \%$ & $0 \%$ & $0 \%$ \\
\hline Logitech international & $\overline{T H E}$ & $42 \%$ & $55 \%$ & $95 \%$ & $5 \%$ & $0 \%$ & $0 \%$ & $0 \%$ \\
\hline
\end{tabular}

ISSN: 07 I8-2724. (http://www.jotmi.org) 


\begin{tabular}{|c|c|c|c|c|c|c|c|c|}
\hline LSI Corp & THE & $13 \%$ & $93 \%$ & $98 \%$ & $0 \%$ & $0 \%$ & $0 \%$ & $2 \%$ \\
\hline Marvell Technology & THE & $0 \%$ & $94 \%$ & $87 \%$ & $11 \%$ & $0 \%$ & $0 \%$ & $2 \%$ \\
\hline Maxim Integrated Products & THE & $21 \%$ & $51 \%$ & $95 \%$ & $5 \%$ & $0 \%$ & $0 \%$ & $0 \%$ \\
\hline MediaTek & THE & $0 \%$ & $90 \%$ & $84 \%$ & $15 \%$ & $0 \%$ & $0 \%$ & $2 \%$ \\
\hline Melexis & THE & $18 \%$ & $18 \%$ & $56 \%$ & $0 \%$ & $0 \%$ & $0 \%$ & $44 \%$ \\
\hline Mellanox Technologies & THE & $63 \%$ & $42 \%$ & $100 \%$ & $0 \%$ & $0 \%$ & $0 \%$ & $0 \%$ \\
\hline MEMC Electronics Materials & $\overline{T H E}$ & $33 \%$ & $44 \%$ & $83 \%$ & $17 \%$ & $0 \%$ & $0 \%$ & $0 \%$ \\
\hline Microchip Technology & THE & $3 \%$ & $68 \%$ & $91 \%$ & $9 \%$ & $0 \%$ & $0 \%$ & $0 \%$ \\
\hline Micron Technology & THE & $34 \%$ & $96 \%$ & $93 \%$ & $0 \%$ & $0 \%$ & $0 \%$ & $7 \%$ \\
\hline Micronic Mydata & THE & $37 \%$ & $89 \%$ & $100 \%$ & $0 \%$ & $0 \%$ & $0 \%$ & $0 \%$ \\
\hline Microsemi & THE & $39 \%$ & $57 \%$ & $76 \%$ & $24 \%$ & $0 \%$ & $0 \%$ & $0 \%$ \\
\hline Motorola & THE & $7 \%$ & $94 \%$ & $100 \%$ & $0 \%$ & $0 \%$ & $0 \%$ & $0 \%$ \\
\hline Muhlbauer & THE & $12 \%$ & $31 \%$ & $100 \%$ & $0 \%$ & $0 \%$ & $0 \%$ & $0 \%$ \\
\hline Murata Manufacturing & THE & $18 \%$ & $88 \%$ & $97 \%$ & $0 \%$ & $0 \%$ & $0 \%$ & $2 \%$ \\
\hline $\mathrm{NCR}$ & THE & $15 \%$ & $59 \%$ & $99 \%$ & $0 \%$ & $0 \%$ & $0 \%$ & $1 \%$ \\
\hline Neopost & THE & $57 \%$ & $89 \%$ & $100 \%$ & $0 \%$ & $0 \%$ & $0 \%$ & $0 \%$ \\
\hline NetApp & THE & $70 \%$ & $99 \%$ & $98 \%$ & $0 \%$ & $0 \%$ & $0 \%$ & $2 \%$ \\
\hline Nokia & THE & $9 \%$ & $95 \%$ & $71 \%$ & $1 \%$ & $2 \%$ & $0 \%$ & $26 \%$ \\
\hline NVIDIA & THE & $7 \%$ & $78 \%$ & $57 \%$ & $43 \%$ & $0 \%$ & $0 \%$ & $0 \%$ \\
\hline NXP Semiconductors & THE & $0 \%$ & $80 \%$ & $100 \%$ & $0 \%$ & $0 \%$ & $0 \%$ & $0 \%$ \\
\hline Oclaro & THE & $74 \%$ & $76 \%$ & $19 \%$ & $81 \%$ & $0 \%$ & $0 \%$ & $0 \%$ \\
\hline OmniVision Technologies & THE & $39 \%$ & $77 \%$ & $63 \%$ & $2 \%$ & $0 \%$ & $0 \%$ & $35 \%$ \\
\hline ON Semiconductor & THE & $36 \%$ & $75 \%$ & $41 \%$ & $55 \%$ & $0 \%$ & $0 \%$ & $4 \%$ \\
\hline Option & THE & $14 \%$ & $18 \%$ & $91 \%$ & $9 \%$ & $0 \%$ & $0 \%$ & $0 \%$ \\
\hline PACE & THE & $33 \%$ & $51 \%$ & $85 \%$ & $15 \%$ & $0 \%$ & $0 \%$ & $0 \%$ \\
\hline Parrot & THE & $32 \%$ & $42 \%$ & $100 \%$ & $0 \%$ & $0 \%$ & $0 \%$ & $0 \%$ \\
\hline Pitney Bowes & THE & $35 \%$ & $91 \%$ & $99 \%$ & $0 \%$ & $0 \%$ & $0 \%$ & $1 \%$ \\
\hline Plantronics & THE & $29 \%$ & $61 \%$ & $100 \%$ & $0 \%$ & $0 \%$ & $0 \%$ & $0 \%$ \\
\hline PMC-Sierra & THE & $57 \%$ & $64 \%$ & $7 \%$ & $93 \%$ & $0 \%$ & $0 \%$ & $0 \%$ \\
\hline Polycom & THE & $36 \%$ & $60 \%$ & $100 \%$ & $0 \%$ & $0 \%$ & $0 \%$ & $0 \%$ \\
\hline Promethean World & THE & $45 \%$ & $45 \%$ & $100 \%$ & $0 \%$ & $0 \%$ & $0 \%$ & $0 \%$ \\
\hline Qlogic & THE & $43 \%$ & $43 \%$ & $100 \%$ & $0 \%$ & $0 \%$ & $0 \%$ & $0 \%$ \\
\hline Qualcomm & THE & $12 \%$ & $96 \%$ & $100 \%$ & $0 \%$ & $0 \%$ & $0 \%$ & $0 \%$ \\
\hline Quantum & THE & $50 \%$ & $60 \%$ & $90 \%$ & $10 \%$ & $0 \%$ & $0 \%$ & $0 \%$ \\
\hline Radiall & THE & $62 \%$ & $62 \%$ & $77 \%$ & $0 \%$ & $0 \%$ & $0 \%$ & $23 \%$ \\
\hline Rambus & THE & $27 \%$ & $83 \%$ & $87 \%$ & $13 \%$ & $0 \%$ & $0 \%$ & $0 \%$ \\
\hline Research in motion & THE & $18 \%$ & $95 \%$ & $97 \%$ & $1 \%$ & $0 \%$ & $0 \%$ & $2 \%$ \\
\hline RF Micro Devices & THE & $46 \%$ & $69 \%$ & $100 \%$ & $0 \%$ & $0 \%$ & $0 \%$ & $0 \%$ \\
\hline Ricoh & THE & $25 \%$ & $92 \%$ & $99 \%$ & $0 \%$ & $0 \%$ & $0 \%$ & $1 \%$ \\
\hline Riverbed technology & THE & $67 \%$ & $58 \%$ & $100 \%$ & $0 \%$ & $0 \%$ & $0 \%$ & $0 \%$ \\
\hline SanDisk & THE & $43 \%$ & $97 \%$ & $85 \%$ & $11 \%$ & $0 \%$ & $3 \%$ & $0 \%$ \\
\hline Semiconductor Manufacturing SMIC & THE & $61 \%$ & $78 \%$ & $2 \%$ & $98 \%$ & $0 \%$ & $0 \%$ & $0 \%$ \\
\hline Silicon Image & THE & $58 \%$ & $79 \%$ & $100 \%$ & $0 \%$ & $0 \%$ & $0 \%$ & $0 \%$ \\
\hline Silicon Laboratories & THE & $14 \%$ & $66 \%$ & $100 \%$ & $0 \%$ & $0 \%$ & $0 \%$ & $0 \%$ \\
\hline Skyworks Solutions & $\overline{T H E}$ & $41 \%$ & $77 \%$ & $99 \%$ & $1 \%$ & $0 \%$ & $0 \%$ & $0 \%$ \\
\hline
\end{tabular}

ISSN: 07 I8-2724. (http://www.jotmi.org) 


\begin{tabular}{|c|c|c|c|c|c|c|c|c|}
\hline Smartrac & THE & $46 \%$ & $54 \%$ & $85 \%$ & $15 \%$ & $0 \%$ & $0 \%$ & $0 \%$ \\
\hline Sonus Networks & THE & $20 \%$ & $20 \%$ & $100 \%$ & $0 \%$ & $0 \%$ & $0 \%$ & $0 \%$ \\
\hline Spirent Communications & THE & $67 \%$ & $100 \%$ & $0 \%$ & $100 \%$ & $0 \%$ & $0 \%$ & $0 \%$ \\
\hline Spreadtrum Communications & THE & $25 \%$ & $37 \%$ & $0 \%$ & $100 \%$ & $0 \%$ & $0 \%$ & $0 \%$ \\
\hline STMicroelectronics & THE & $0 \%$ & $87 \%$ & $1 \%$ & $69 \%$ & $1 \%$ & $8 \%$ & $22 \%$ \\
\hline Suss MicroTec & THE & $35 \%$ & $30 \%$ & $87 \%$ & $13 \%$ & $0 \%$ & $0 \%$ & $0 \%$ \\
\hline Synaptics & THE & $79 \%$ & $64 \%$ & $100 \%$ & $0 \%$ & $0 \%$ & $0 \%$ & $0 \%$ \\
\hline TCL Communication Technology & THE & $19 \%$ & $39 \%$ & $3 \%$ & $93 \%$ & $0 \%$ & $0 \%$ & $3 \%$ \\
\hline Teradyne & THE & $36 \%$ & $64 \%$ & $62 \%$ & $38 \%$ & $0 \%$ & $0 \%$ & $0 \%$ \\
\hline Tessera Technologies & THE & $65 \%$ & $83 \%$ & $82 \%$ & $18 \%$ & $0 \%$ & $0 \%$ & $0 \%$ \\
\hline Texas Instruments & THE & $5 \%$ & $91 \%$ & $85 \%$ & $7 \%$ & $8 \%$ & $0 \%$ & $0 \%$ \\
\hline Triquint Semiconductor & THE & $48 \%$ & $72 \%$ & $100 \%$ & $0 \%$ & $0 \%$ & $0 \%$ & $0 \%$ \\
\hline VeriFone Systems & THE & $70 \%$ & $70 \%$ & $95 \%$ & $0 \%$ & $0 \%$ & $0 \%$ & $5 \%$ \\
\hline Western Digital & THE & $35 \%$ & $79 \%$ & $81 \%$ & $19 \%$ & $0 \%$ & $0 \%$ & $0 \%$ \\
\hline Wistron & THE & $17 \%$ & $72 \%$ & $78 \%$ & $18 \%$ & $2 \%$ & $0 \%$ & $1 \%$ \\
\hline Wolfson Microelectronics & THE & $36 \%$ & $69 \%$ & $100 \%$ & $0 \%$ & $0 \%$ & $0 \%$ & $0 \%$ \\
\hline Xaar & THE & $100 \%$ & $100 \%$ & $100 \%$ & $0 \%$ & $0 \%$ & $0 \%$ & $0 \%$ \\
\hline Xerox & THE & $26 \%$ & $86 \%$ & $45 \%$ & $0 \%$ & $0 \%$ & $0 \%$ & $55 \%$ \\
\hline Xilinx & THE & $38 \%$ & $93 \%$ & $100 \%$ & $0 \%$ & $0 \%$ & $0 \%$ & $0 \%$ \\
\hline Xyratex & THE & $27 \%$ & $40 \%$ & $0 \%$ & $100 \%$ & $0 \%$ & $0 \%$ & $0 \%$ \\
\hline ZTE & THE & $11 \%$ & $91 \%$ & $99 \%$ & $1 \%$ & $0 \%$ & $0 \%$ & $0 \%$ \\
\hline
\end{tabular}


B) List of joint ventures and their shareholders

\begin{tabular}{|c|c|}
\hline Joint venture & Shareholder \\
\hline Aptina Imaging & Micron Technology \\
\hline Dow Corning & Corning \\
\hline Draka Comteq BV & Alcatel-Lucent \\
\hline eLith & Applied Materials;ASML Holding \\
\hline Ericsson-LG & Ericsson \\
\hline Fuji Xerox & Xerox \\
\hline Globalfoundries & Advanced Micro Devices \\
\hline Huada Digital & HTC \\
\hline Huawei Marine Networks & Huawei Technologies \\
\hline Huawei Symantec & Huawei Technologies \\
\hline Infineon Technologies Bipolar & Infineon Technologies \\
\hline InfoPrint Solutions & Ricoh \\
\hline Inotera & Micron Technology \\
\hline Intel-GE Care Innovations & Intel \\
\hline Kirin-Amgen & Amgen \\
\hline Leshan Phoenix Semi & ON Semiconductor \\
\hline LS Power Semitech & Infineon Technologies \\
\hline MAZ Mikroelektronic-Anwendungszentrum & ELMOS Semiconductor \\
\hline Nokia Siemens Network & Nokia \\
\hline OraSense & Isis; Elan \\
\hline PreAnalytiX & Qiagen \\
\hline Raydiall & Radiall \\
\hline Richter-Helm BioTec & GedeonRichter \\
\hline Samsung Corning & Corning \\
\hline Sanofi Minsheng & Sanofi \\
\hline Sanofi Pasteur MSD & Sanofi; MerckUS \\
\hline Silicon Optronics & OmniVision Technologies \\
\hline SMP & MEMC Electronics Materials \\
\hline Sony Ericsson & Ericsson \\
\hline ST-Ericsson & Ericsson; STMicroelectronics \\
\hline ST-NXP & STMicroelectronics; NXP Semiconductors \\
\hline Tech Semiconductor Singapore & Micron Technology; Canon; Hewlett-Packard \\
\hline Transform Solar & Micron Technology \\
\hline ViiV Healthcare & GSK; Pfizer \\
\hline VisEra & OmniVision Technologies \\
\hline Wuhan Xinxin & Semiconductor Manufacturing SMIC \\
\hline
\end{tabular}

